\title{
A REVISION OF THE AMPHIPOD GENUS MICRODEUTOPUS COSTA (GAMMARIDEA : AORIDAE)
}

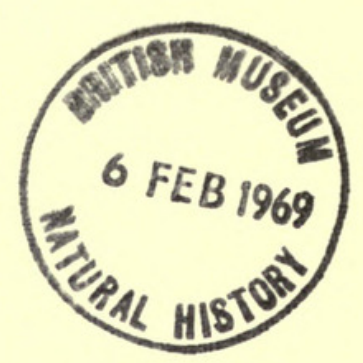

BY



Pp. 9I-I48; I Plate, 22 Text-figures

BULLETIN OF

THE BRITISH MUSEUM (NATURAL HISTORY) ZOOLOGY Vol. I 7 No. 4 
THE BULLETIN OF THE BRITISH MUSEUM (NATURAL HISTORY), instituted in r949, is issued in five series corresponding to the Departments of the Museum, and an Historical series.

Parts will appear at irregular intervals as they become ready. Volumes will contain about three or four hundred pages, and will not necessarily be completed within one calendar year.

In I965 a separate supplementary series of longer papers was instituted, numbered serially for each Department.

This paper is Vol. I7, No. 4 of the Zoological series. The abbreviated titles of periodicals cited follow those of the World List of Scientific Periodicals.

World List abbreviation:

Bull. Br. Mus. nat. Hist. (Zool.).

(C) Trustees of the British Museum (Natural History) r969

TRUSTEES OF

THE BRITISH MUSEUM (NATURAL HISTORY)

Issued 4 February, r969

Price $£^{\mathrm{I}} 5^{s}$. 


\title{
A REVISION OF THE AMPHIPOD GENUS MICRODEUTOPUS COSTA (GAMMARIDEA : AORIDAE)
}

\author{
A. A. MYERS
}

\section{SY NOPSIS}

The systematic position of the Aoridae and the phylogenetic relationships of its members are discussed. All the known species of Microdeutopus and one new species are described and figured, with keys for their identification. The synonymy of each species of Microdeutopus is reviewed, and details of their ecology and distribution are given. A catalogue of material studied in the present work, and the location of type material, is given in the appendices.

\section{INTRODUCTION}

THE need for a revision of a number of genera in the Aoridae has long been indicated. Enequist (I949) pointed out that there is uncertainty about the delimitation of the species of the genera Microdeutopus and Lembos. Andersson (I954) elucidated the relationships of Microdeutopus gryllotalpa Costa, $M$. anomalus (Rathke) and $M$. propinquus Sars, using material collected in the Gullmarfjord and collections in the Swedish State Museum. His findings have been substantiated in the present work, which included studies on laboratory-reared material. Generally, however, field workers have experienced difficulties in the identification of aorid material, as is clear from the numbers of wrongly identified specimens that exist in many institutions. The literature is so widely scattered, and the synonymy, particularly of the European species, so confused, that a thorough revision of the synonymy and review of the literature are needed.

During the present investigations, fresh material was examined wherever possible together with preserved material from the British Museum and a number of other institutions and specimens from private donors (see Appendix I). Laboratory reared material of $M$. gryllotalpa and $M$. anomalus was also studied.

Identification of Aoridae is frequently hindered by their fragility, specimens collected in dredge samples often being devoid of all appendages except gnathopoda, pleopoda and uropoda. Fortunately male Microdeutopus species can readily be identified by the structure of the gnathopoda, uropoda and telson, and by the form of the processes which arise from the peraeon segments in the mid-ventral line. These ventral processes have been shown to occur in all species of Microdeutopus which have been examined for this character. The only species not examined is $M$. haswelli Stebbing, which at this stage seems better not dissected since it is represented only by the single holotype specimen obtained on loan from the Australian Museum, Sydney.

In general, the structure of the mouthparts is not a valuable taxonomic criterion, except at a generic level and above, though in some species, certain minor differences zOOL. I7, 4 
can be recognized as in the structure of the mandibular processes of the paragnath in $M$. schmitti Shoemaker and $M$. hancocki Myers.

Kinne (I963a, I963b, I964) has shown that temperature, salinity, food, and combinations of these factors affect maximum size in some organisms. Personal observations in the laboratory (Myers, I968d) indicate that some, if not all these factors, also affect growth rates and maximum size in $M$. gryllotalpa and presumably, therefore, in other Microdeutopus species. Field observations also suggest that the various species reach differing maximum sizes, in different localities, and it is therefore not possible to give an overall indication of the size at which the male of any Microdeutopus species reaches maturity and is hence identifiable. In particular it should be noted that high latitude specimens are generally much larger than low latitude specimens of the same species. In the systematic section the maximum recorded size, measured from the anterior margin of the cephalosome to the tip of the telson, is given for each species and each sex.

Male Microdeutopus are readily identifiable, and descriptions of all known species are given below, together with keys for their identification. The identification of females presents considerable difficulty, however, since aorid genera are based almost entirely upon adult male characters, of forms which show extensive sexual dimorphism. There are no characters exhibited by females which are diagnostic of the genus Microdeutopus. Many resemble the male in the structure of the antennules, antennae, uropoda and telson, thus exhibiting features which differ in one way or another from those of other Microdeutopus females, and probably from those of other female Aoridae. However, until the females of all the known Aoridae are studied, identification of solitary females within this family must remain questionable. Full descriptions and figures of ovigerous females, are given here, to aid provisional identification and also to prevent the confusion of females in samples containing more than one Microdeutopus species.

\section{SYSTEMATIC POSITION OF THE AORIDAE}

The Aoridae are closely related to the Photidae, from which they differ in having the first pair of gnathopoda more markedly developed than the second. Aorcho Barnard is intermediate in having the first and second gnathopoda of equal size and can be assigned to either family (Barnard, I964). Also intimately related to the Aoridae are the Corophiidae, which differ from the Aoridae only in the degree of depression of the pleon. The loss of the accessory flagellum of the antennule has been described as an advanced character in Amphipoda (Barnard, I962), and it is suggested here that the corophiid tendency towards the loss of a uropod 3 ramus is also advanced, so does not necessarily indicate close relationship between the possessors of this character. Barnard (Ig62) has pointed out that it has become increasingly difficult to assign, between the two families, various members of the Photidae and Corophiidae, because here too the differences involve quantitative aspects of depression or compression of the pleon. It seems probable that the family Corophiidae is polyphyletic and includes, within its framework, advanced members of both the Aoridae and Photidae. It is therefore not possible to indicate any circum- 
scribed diagnosis for the family Aoridae, which can only be described as those members of the aorid/photid/ischyrocerid/corophiid complex which exhibit greater development of gnathopod I than gnathopod 2, coupled with a tendency towards retention of such primitive characters as an accessory flagellum on the antennule, uropod 3 with two rami, contiguous coxae, and no marked depression of the pleon.

The subdivision of the family Aoridae is also problematical since the complex permutations of characters among the species makes a systematic classification, based on possible phylogenetic relationships, exceedingly difficult. The accessory flagellum of the antennule exhibits a complete gradation of stages, from (a) primitively multi-articulate as in Aora typica Kroyer, Microdentopus anomalus (Rathke), Lembopsis spinicarpus Pearse, Lembos viguieri Chevreux and others, to (b) reduced to two or three articles of which the terminal one is usually vestigial, e.g. in Microdeutopus armatus Chevreux, Lemboides afer Stebbing, and Neomegamphopus roosevelt $i$ Shoemaker, or microscopic as in Aoroides columbiae Walker. The rami of uropod 3 may be (a) more or less equally developed as in Amphideutopus oculatus Barnard, Microdeutopus versiculatus (Bate), Lembos longipes Lilljeborg, and Aorcho delgadus Barnard; (b) the endopodite may be greatly reduced as in Acuminodeutopus heteruropus Barnard; (c) both rami may be minute, as in Paradryope orguion Stebbing and Dryopoides westwoodi Stebbing; or (d) there may be a single ramus only as in Neomicrodentopus cabindae Schellenberg. The antennae exhibit considerable variation in form. They may be (a) shorter than the antennules stout, sub-pediform, with few flagellar articles, resembling those of the Corophiidae, as in Microdeutopus haswelli Stebbing; (b) less stout, as in M. gryllotalpa Costa, Aora typica Kroyer, Lembos websteri Bate and Lemboides afer Stebbing; (c) slender though still shorter than the antennules, as in Microdeutopus stationis Della Valle, Lembopsis spinicarpus Pearse and Lembos macromanus (Shoemaker); or (d) very long and slender, exceeding the length of the antennules, with multiarticulate flagella, as in Paradryope orguion Stebbing and Amphideutopus dolichocephalus Myers. The development of median spines on the ventral surface of the peraeon segments is of frequent occurrence in the Aoridae, but such spines are not restricted to the Aoridae, being also exhibited by various members of the related family Corophiidae, including certain species of Unciola Say and Grandidierella Coutière.

Most classifications of the Aoridae have been based upon the structure of the male gnathopod I, the gross development of which is so characteristic a feature of the Aoridae, though it is not diagnostic. Two main tendencies are discernible in this appendage: first, the great development of one or more of the articles, frequently accompanied by reduction of some of the others, and secondly, the production of toothlike processes on one or more of the articles. Classifications based on either of these characters are arbitrary, since it would be unreasonable to assume that either of these tendencies has occurred only once in the evolution of the family. Nevertheless, a good workable classification is that of Barnard (I958, I962, I964) which is adopted here with two important modifications suggested by present work. Firstly Microdeutopus tridens Schellenberg and $M$. kraemmeri Reid are transferred to the genus Lembopsis Pearse (see Myers I968c); and secondly, the genus Coremapus Norman is incorporated in the genus Microdeutopus (see p. I02). 


\section{Genus MICRODEUTOPUS Costa 1853}

Microdeutopus Costa, $\mathrm{I} 853: \mathrm{I} 78$.

Autonoe Bruzelius, I859 (pro-parte): 23.

Stimpsonia Bate, I862 : I62.

Microdeuteropus Norman, I868:281.

Stimpsonella Della Valle, I893: 42 I.

Coremapus Norman, $1905: 78$.

TyPe SPECIES: Microdeutopus gryllotalpa Costa.

DiAGNOSIs. Head lobes moderately produced, obtuse; antennules longer than the antennae (with the exception of male $M$. chelifer (Bate)); article I of mandibular palp the shortest, article 3 the longest, article 3 broad centrally, narrowing terminally; mandibular process of paragnath acute; gnathopod I of male larger than gnathopod 2 , complexly chelate, article 5 considerably larger than article 6 ; females with the first and second gnathopods dissimilar; uropod 3 with two more or less subequal rami; telson simple.

Historical. The genus was established by Costa (I853) to include the single species $M$. gryllotalpa Costa, independently described by Bruzelius under the name Autonoe grandimana. Bate (I856) erected the genus Lembos to include the species $L$. cambriensis Bate, L. damnoniensis Bate, L. versiculatus Bate and $L$. websterii Bate, but later (I862) relegated all these species to the genus Microdeutopus Costa (corrected from Microdentopus in the text, to Microdeutopus in the appendix). In the same year he erected the genus Stimpsonia, to include as monotype chelifera Bate, while admitting that " the genus probably bears too close a resemblance to Microdeutopus to be retained as generically distinct ". Della Valle (I893) noted the preoccupation of Stimpsonia among the Nemertina (Stimpsonia Girard, I853) and erected Stimpsonella, including in the genus, armatus Chevreux with chelifera Bate. Norman (I868) altered Microdeutopus to Microdeuteropus for grammatical reasons but later (Norman, I905a) reverted to the original spelling. Norman (I905b) erected the monotypic genus Coremapus for versiculatus Bate.

Literature. The best general account is that of Della Valle (I893) who gives ten species. Of these, however, $M$. gryllotalpa Costa and $M$. minax Smith are synonymous, $M$. tenuis Dana is not a species of Microdeutopus and $M$. titii Heller is a dubious species, while the distinct species $M$. versiculatus is treated as a synonym of $M$. anomalus Rathke. The keys, which apply to males only, are adequate. Stebbing (I906) gives a good account of eight species, and not eleven as it would seem, for $M$. anomalus (Rathke) and $M$. propinquus Sars are synonymous, M. megnae Giles is attributable to Grandidierella Coutière, and the doubtful M. titii Heller is listed with reservation. Descriptions of the females are inadequate, as in most literature, but the keys which apply to males only are adequate. Chevreux and Fage (I925) give seven species and their keys are modified after Stebbing (I906). Barnard (I958) gives a catalogue of species, and other useful taxonomic works are those of Haswell (I882) describing I sp. from Australia, Sars (I894) 2 spp. from Norway, Stephenson (I929a) 2 spp. North Sea and Baltic, Shoemaker (I938) I sp. Mexico, Schellenberg (I942) 2 spp. Germany, Gurjanova (I95I) 3 spp. U.S.S.R. and Myers (Ig68b) $3 \mathrm{spp}$. Central America. 


\section{Key to the Male MICRODEUTOPUS of the World}

N.B. in most figures of limbs, article $\mathrm{I}$ is omitted so article 2 is the most proximal shown.

I a. Gnathopod 2 chelate

b. Gnathopod 2 not chelate

2 a. Gnathopod 2 with articles 5 and 6 subequal in length and breadth, article 2 expanded, crenulated on anterior margin (Text-fig. I8d)

M. armatus (p. I29)

b. Gnathopod 2 with article 6 much shorter and broader than article 5, article 2 unexpanded, anterior margin smooth, (Text-fig. I9c)

M. chelifer (p. I32)

3 a. Gnathopod I with the anterior margin of article 5 produced into a single tooth. Accessory tooth if present, arising within the posterior margin (Text-fig. $8 \mathrm{~b}$ ) .

b. Gnathopod I with article 5's anterior margin produced into 2 or more teeth (Textfig. 2a)

4 a. Gnathopod 2 densely setose, the setae finely pectinate; article 4 extending over greater length of article 5 (Text-fig. $3 \mathrm{i}$ )

M. versiculatus (p. IоI)

b. Gnathopod 2 moderately setose, the setae not pectinate; article 4 relatively short (Text-fig. 9c) .

(" anomalus" group)

5 a. Gnathopod 2 with articles 5 and 6 short and broad, palmar angle of article 6 almost transverse (Text-fig. 9a); uropod 3 with rami relatively short and broad

M. damnoniensis (p. II4)

b. Gnathopod 2 with articles 5 and 6 slender, elongate, palmar angle of article 6 oblique (Text-fig. 9c); uropod 3 with rami relatively elongate and slender (Text-fig. 9e) .

6 a. Gnathopod $\mathrm{I}$ with the anterior distal margin of article 5 produced into a slender, straight or inwardly curved tooth, generally with an accessory tooth arising near its base within the posterior margin (Text-fig. 8b) .

M. anomalus (p. IIo)

b. Gnathopod I with article 5's anterior margin produced into a broad based stout tooth, never with accessory tooth (Text-fig. $8 \mathrm{~h}$ )

M. algicola (p. II 7 )

7 a. Gnathopod I with article 5 having the proximal (outer) of two teeth longer than the other (Text-figs. 2e, 22a)

b. Gnathopod I's article 5 not as above

8 a. Antenna stout, subpediform, with the first flagellar article grossly developed (Text-fig. 4b); gnathopod 2 with article 2 elongate and slender (Text-fig. $3 \mathrm{~h}$ )

M. haswelli (p. I07)

b. Antenna relatively slender, the first flagellar article not as above (Text-fig. 2I), gnathopod 2 with article 2 broad and short (Text-fig. 22g) . M. sporadhi (p.I36).

9 a. Gnathopod I with the distal tooth on article 5 the longest (Text-fig. 2 b) IO

b. Gnathopod I with the central tooth on article 5 the longest (Text-fig. $2 \mathrm{~d}$ )

M. stationis (p. I04)

Io a. Gnathopod 2 with article 2 convex anteriorly, crenated on the anterior margin



b. Gnathopod 2 with article 2 concave anteriorly and its anterior margin smooth (Text-fig. I4l) . . . . . . . . . . ("schmitti" group) 3 3 


\title{
Microdeutopus gryllotalpa Costa
}

\author{
(Text-figs. Ia, 2a-c, 3a-c, g, m, 5b, 6c-d, 20a)
}

Microdeutopus gryllotalpa Costa, I853 : I78; Costa, I857 : 231, pl. 4, fig. Io; Boeck, I87o : I56; Boeck, I876 : 565, pl. 29, fig. 6; Blanc, I884: 75, pl. 4, figs. 82-9o; Hoek, I889 : 226; Della Valle I893 : 4II, pl. I, fig. I2, pl. II, figs. 25-43; Sars I894: 543, pl. I92, fig. 2; Sowinsky I895: 237, pl. 4, fig. 6; Sowinsky, I898: 480; Stebbing, I906:590; Norman, I907 : 368 , pl. I6, fig. 3, pl. I7, figs. 6-7; Chevreux \& Fage, I925 : 299, fig. 310; Stephenson, I927: I24; Stephensen, I929a : I5I, fig. 273; Oldevig, I933 : 213, fig. 95; Cecchini \& Parenzan, I934 : 213, fig. 43; Loven, I934: 6-8, fig. 2; Miloslavskaia, I939a : I21; Schellenberg, I942 : I86, fig. I54; Soika, I949 : I99; Gurjanova, I95I : 83I, fig. 580; Barnard, I958 : 29.

[Non] Microdeutopus gryllotalpa Bate, I862: 163, pl. 30, fig. I.

[Non] Microdeutopus gryllotalpa Nebeski, I88o: 45, fig. 4I.

[Non] Microdeutopus grillotalpa [sic] Sowinsky, r88o: 125, pl. 5, fig. I7 a-d.

Autonoe grandimana Bruzelius, $1859: 26$, pl. I, fig. 5 .

Microdeutopus grandimanus (Bruzelius) Bate, $1862: 378$.

Microdeutopus minax Smith, $1874: 562$.

Microdeutopus bidens Sowinsky, I880 : 129, pl. 5, fig. I8.

[?]Amphithoe salenskii Carus, $1885: 396$.

Microdeuteropus gryllotalpa (Costa) Norman, I886 : I6; Chevreux \& Bouvier, I893 : I33.

Microdeuteropus minax (Smith) Norman, I886: I7.

TyPe Locality. Lago di Fusaro, Italy.

Diagnosis of male. Antennule about half the body length, the first peduncular article slightly shorter than the second, the third about one third the length of the second; flagellum longer than the peduncle normally with up to twenty-two articles (maximum recorded twenty-six); accessory flagellum with two articles, the second article rudimentary. Antenna slightly under two thirds the length of the antennule, the fourth and fifth peduncular articles subequal; flagellum shorter than the fifth peduncular article, normally with up to nine articles (maximum recorded eleven). Peraeon segments $2-7$ each with a process in the mid-ventral line, those of segments 2 and 3 short, straight, those of segments $4-7$ short, robust, posteriorly directed; processes 6 and 7 with short setae arising from their posterior margins. Gnathopod I with article I moderately produced anteriorly, acute; article 2 short and expanded distally; article 5 immensely expanded, in some specimens as broad as long, the posterior distal margin produced into two to four teeth, of which the most distal is always the longest; article 6 short, the posterior margin irregularly lobed; article 7 sometimes short and robust, sometimes relatively long and slender. Gnathopod 2 with article 2 greatly expanded, the anterior margin convex and crenated; articles 5 and 6 subequal in length, 5 slightly the broader, articles 4,5 and 6 with long pectinate setae on the anterior margins. Uropod 3 with rami equal in length to the peduncle exopodite slightly the longer of the two rami; each ramus with a transverse row of three closely associated spines on the outer dorsal margin, together with a number of paired and solitary spines of variable distribution, terminal setae relatively long. Telson with each terminal crest bearing on its distal dorsal margin, a group of up to six setae.

Maximum size of male: $8 \mathrm{~mm}$. 
Female. As the male except for the absence of ventral peraeon processes and the structure of the sexually dimorphic gnathopoda.

Gnathopod I with article 2 moderately expanded; articles 5 and 6 subequal in length, 5 slightly the broader, 6 with the anterior and posterior margins roughly parallel; article 7 equal in length to the angular palmar region. Gnathopod 2 with
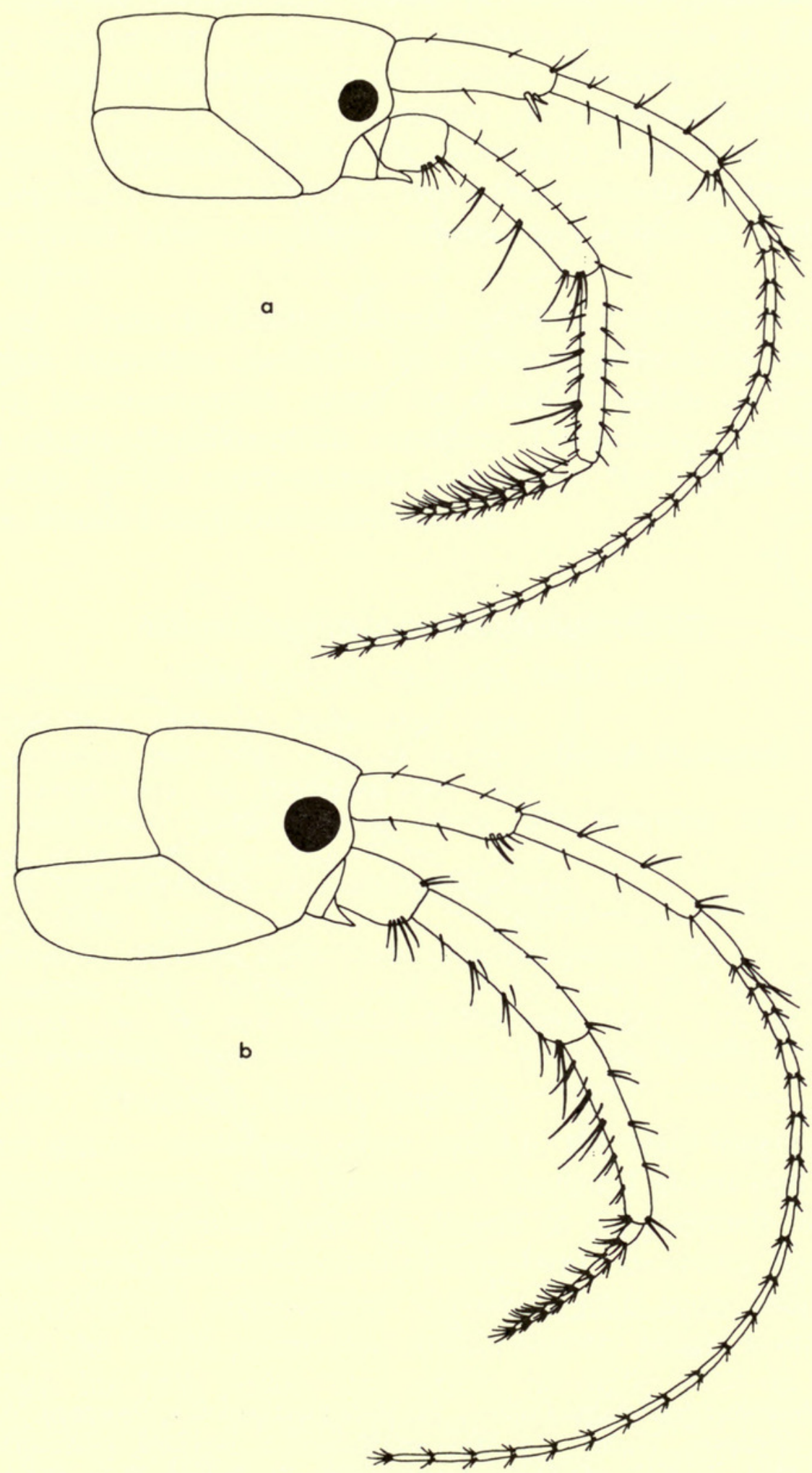

Fig. I. Microdeutopus gryllotalpa Costa. (a) Male head, Swansea, Wales. Microdeutopus versiculatus (Bate). (b) Male head, Falmouth Harbour, England. 
article 2 slightly expanded, crenulated on the anterior margin; articles 5 and 6 elongate, subequal; articles 4,5 and 6 with pectinate setae on their anterior margins.

Maximum size of female: Io $\mathrm{mm}$.

Discussion. $M$. gryllotalpa is closely related to $M$. versiculatus but differs in both sexes by the second gnathopod (Text-figs. $3 \mathrm{~g}, 5 \mathrm{~b}$ ) not having the fourth article greatly produced along the posterior border of the fifth, nor the fifth and sixth

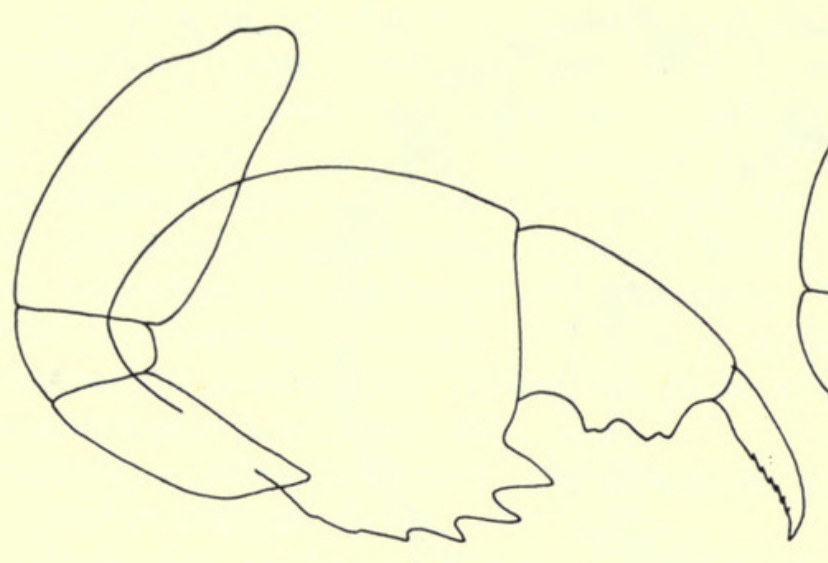

a
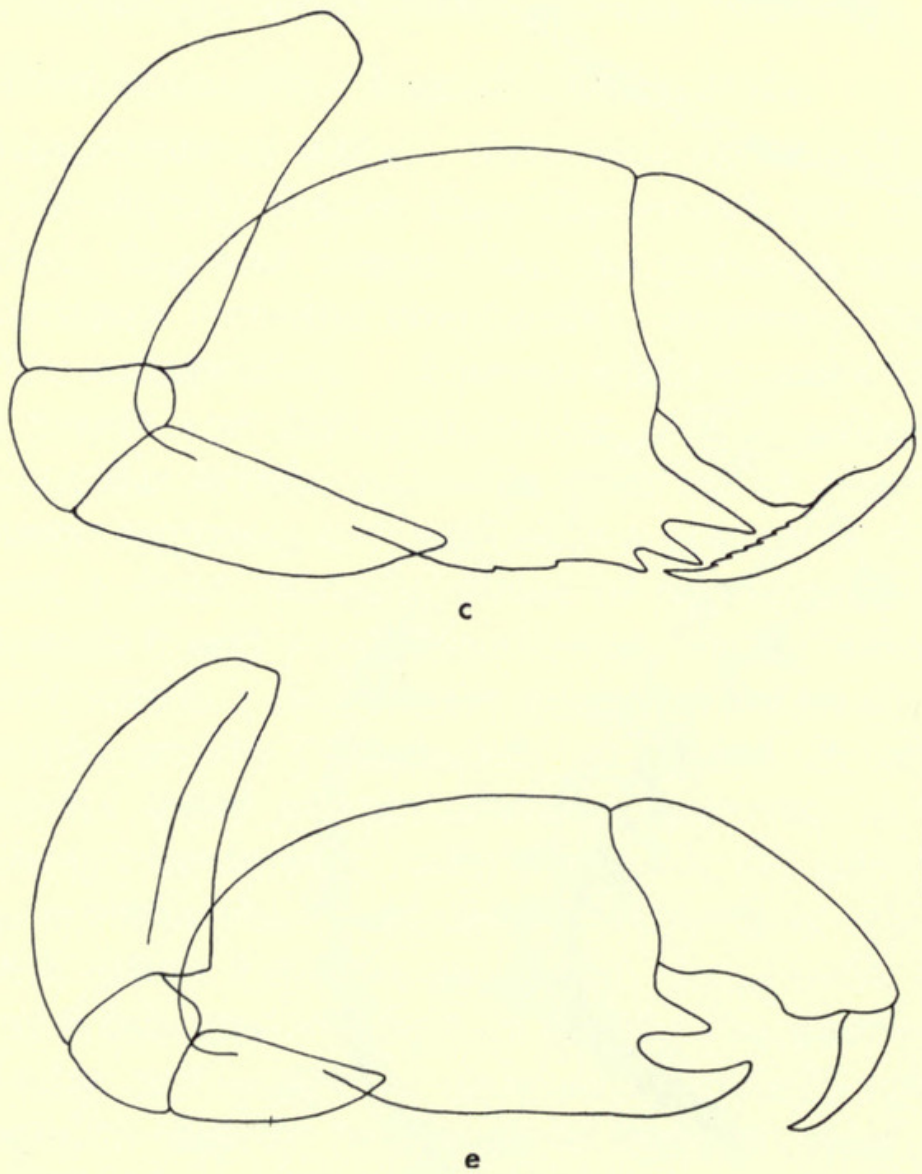

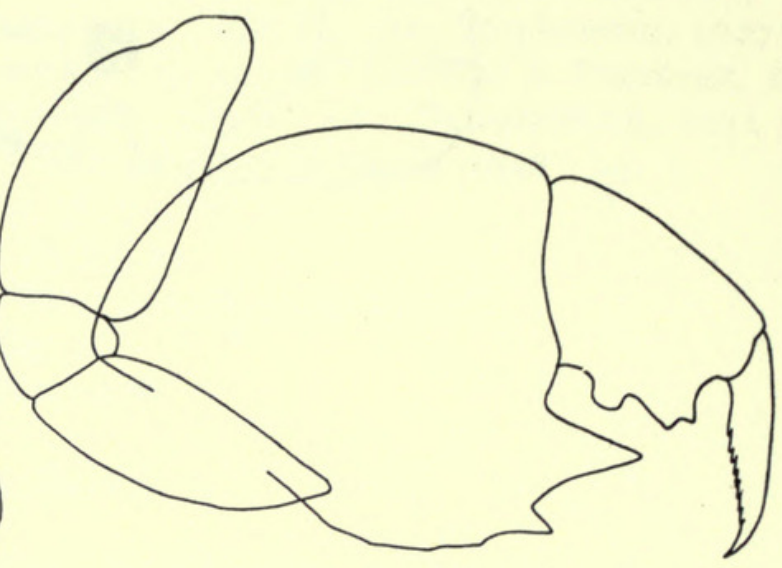

b

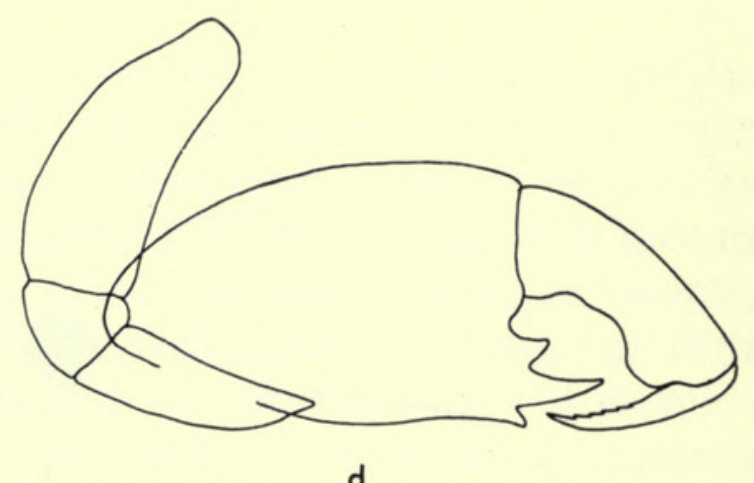

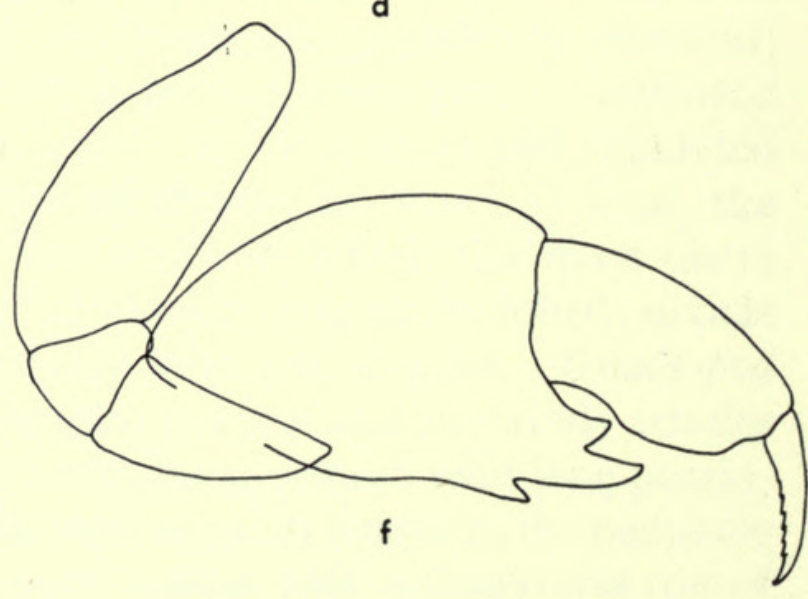

Fig. 2. Microdeutopus gryllotalpa Costa. (a) Male gnathopod I, Swansea, Wales. (b) Male gnathopod I, Swansea, Wales. (c) Male gnathopod I, Isefjord, Denmark. Microdeutopus stationis Della Valle. (d) Male gnathopod I, St. Peter's Port, Guernsey. (f) Male gnathopod I, Naples, Italy. Microdeutopus haswelli Stebbing. (e) Male gnathopod I, Port Jackson, Australia (Holotype). 
articles so markedly elongate and slender. Females of $M$. gryllotalpa are readily identifiable by the structure of the fifth article of the second gnathopod (Text-fig. 5b), which has long pectinate setae arising from the entire length of the anterior margin, whereas in all other Microdeutopus species (except $M$. versiculatus) the long setae arise from the anterior corner only of the fifth article.

Ecology. In the intertidal zone in rock pools amongst Chaetomorpha and other algae; amongst Zostera spp.; and in salt marshes (Chevreux \& Fage, I925), often associated with Ruppia maritima as at Roscoff (Truchot, I963). Also occurring sub-littorally to a depth of about I50 metres on oyster beds, and amongst algae, tunicates, sponges, polyzoans, Mytilus etc., always in areas of high detritus accumulation. It particularly favours docks and other man-made installations, and is frequently associated with Corophium acherusicum Costa in both the Palearctic and Nearctic regions.

Distribution. From the Lofoten Islands southwards along the coasts of Norway, Sweden, Denmark, including the Baltic, and Holland, around the coasts of the British Isles, chiefly in the south-west, along the Atlantic coasts of France, Spain and Portugal, and in the Mediterranean Ligurian, Tyrrhenean, Adriatic, Aegean and Black Seas. Also, on the north-eastern seaboard of the United States of America (Massachusetts, Rhode Island and Connecticut).

\section{Microdeutopus versiculatus (Bate)}

(Text-figs. Ib, 3i, k, 5a, 6a-b, 20c)

Lembos versiculatus Bate, I856: 58 ; Bate, I 857 : I42.

Microdeutopus versiculatus Bate, I862 : 165, pl. 30, fig. 5; Bate \& Westwood I863 : 295; Walker, I $895: 469$; Chevreux I900 : 89; Stebbing, I906 : 593 .

Microdeuteropus versiculatus (Bate) Norman, I869a: 282; Stebbing, I874: I2, pl. I, figs. 2, 2a-f. Chevreux \& Bouvier, I893 : I34.

Autonoe longipes (Lilljeborg) Boeck, I876 (pro-parte) : 574 .

Autonoe versiculata (Bate) Norman, I886: I7.

Microdeutopus anomalus (Rathke) Della Valle, I893 (pro-parte) : 4I8.

Coremapus versiculatus (Bate) Norman, I905b: 78; Chevreux \& Fage, I925: 30I, fig. 312;

Stephensen, I929a : I52, fig. 276; Cecchini \& Parenzan, I934:217, fig. 45; Miloslavskaia, I939a : 125, fig. 25; Soika, I949 : 200; Gurjanova, I95 I : 835, fig. 585; Barnard, I958 : 29.

Type Locality. Plymouth, Devon, England.

Diagnosis of male. Antennule about equal to the body length, the first peduncular article slightly shorter than the second, the third about one third the length of the second; flagellum almost twice the length of the peduncle, normally with up to twenty articles (maximum recorded twenty-two); accessory flagellum with two articles, the second article rudimentary. Antenna little more than half the length of the antennule, the fourth peduncular article slightly longer than the fifth; flagellum shorter than the fifth peduncular article, normally with up to eight articles (maximum recorded nine). Peraeon segments $2-7$ each with a process in the midventral line; that of segment 2 slender, spiniform, directed anteriorly; those of segments 3 and 4 slender, spiniform, straight; those of $5-7$ robust, decreasing in size antero-posteriorly, with processes 6 and 7 having setae arising from their posterior 
margins. Gnathopod I with article I moderately produced anteriorly, acute; article 2 considerably expanded; article 5 much enlarged, longer than broad, the posterior distal angle produced into a single, robust tooth; article 6 short, the posterior margin irregularly lobed; article 7 short and robust. Gnathopod 2 with article 2 somewhat expanded; article 4 well developed, extending over the greater length of the posterior margin of article 5 ; article 5 longer than article 6 , elongate and slender, about three times as long as broad; article 6 also very long and slender, about three and a half times as long as broad; article 7 very short, long pectinate setae arising from the anterior margins of articles 4, 5 and 6 . Uropod 3 with rami sub-equal, equal in length to the peduncle; exopodite with a transverse row of three closely associated spines on the outer-dorsal margin, basal to which is a solitary spine; endopodite with a similar transverse row of closely associated spines on the outer-dorsal margin, and in addition on the inner margin, a series of well separated spines; terminal setae of both rami relatively long. Telson with each terminal crest bearing on its distal dorsal margin a group of two to three setae.

Maximum size of male: $7 \mathrm{~mm}$.

Female. As the male except for the structure of the sexually dimorphic gnathopoda and absence of ventral peraeon processes. Gnathopod I with article 2 short and considerably expanded, about two thirds as broad as long; article 5 scarcely longer than article 6 , with a dense clothing of comb setae along the entire length of the posterior border; article 6 almost as broad as 5, with the anterior and posterior margins roughly parallel; article 7 moderately long, equal in length to the palmar region. Gnathopod 2 with article 2 elongated and slender, otherwise identical with the corresponding appendage of the male.

Maximum size of female: $8 \mathrm{~mm}$.

Discussion. First designated as a nomen nudum by Bate (I856) the species was later described from the female (Bate, I857, I862). The male was first described by Norman (I868) and later by Stebbing (I874) who also gave figures. The suggestion that a monotypic genus should be erected for this species (Norman, I905b) is not accepted. The present species bears a close relationship with $M$. gryllotalpa Costa in the similarity of the male first gnathopod of the two species. That of $M$. versiculatus (Text-fig. $3 \mathrm{k}$ ) differs in having a single tooth on the posterior distal angle of article 5, whereas in $M$. gryllotalpa (Text-figs. 2a-c) there are two to four. The two species are also similar in the structure of the male second gnathopod. Article 2 of that appendage is expanded, though less markedly in $M$. versiculatus (Text-fig. 3i) than in $M$. gryllotalpa (Text-fig. $3 g$ ) and article 5 has pectinate setae arising from the entire anterior margin (also a character of the female). Finally, males of both species have ventral processes on all peraeon segments except the first. The remarkable slender, setose second gnathopod of $M$. versiculatus (Text-fig. 5a), which led Normon (I905b) to erect a monotypic genus for the species, is an extreme modification of the type found in $M$. gryllotalpa and serves to distinguish $M$. versiculatus in both sexes from all other Microdeutopus species.

ECOLOGY. In the intertidal zone (Oldany, Sutherland), but much more frequently in the sub-littoral to a depth of about I50 metres (off the Shetland Islands) amongst 
REVISION OF MICRODEUTOPUS

IOS

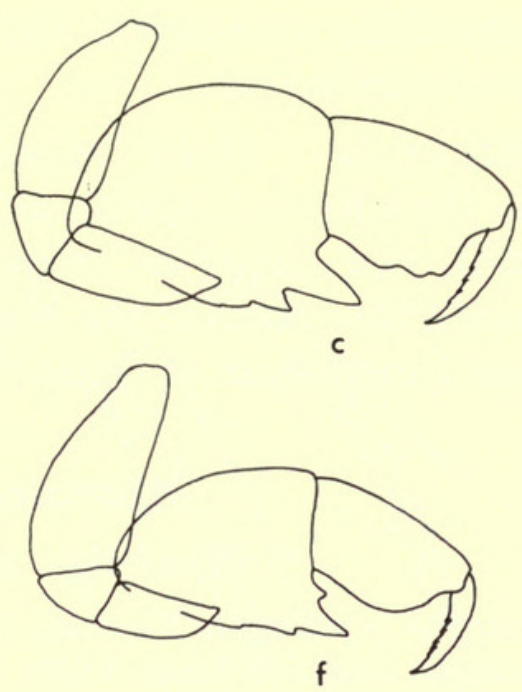

e

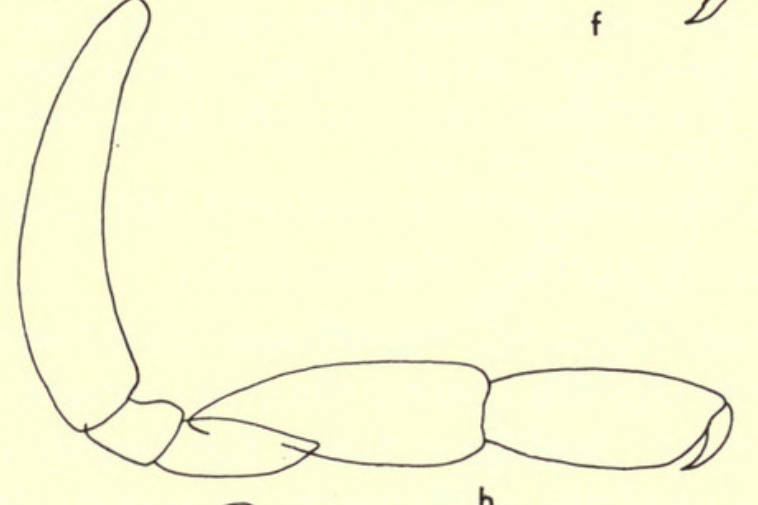

$\mathrm{h}$

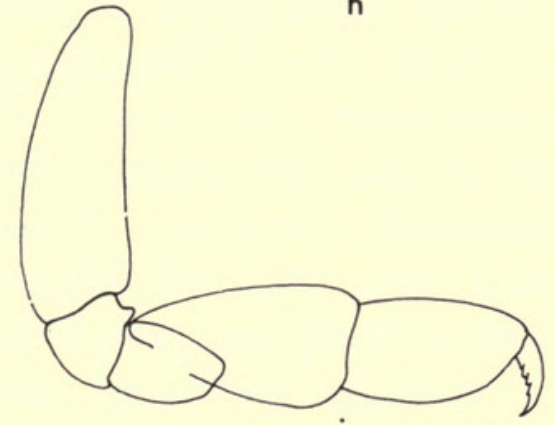

j
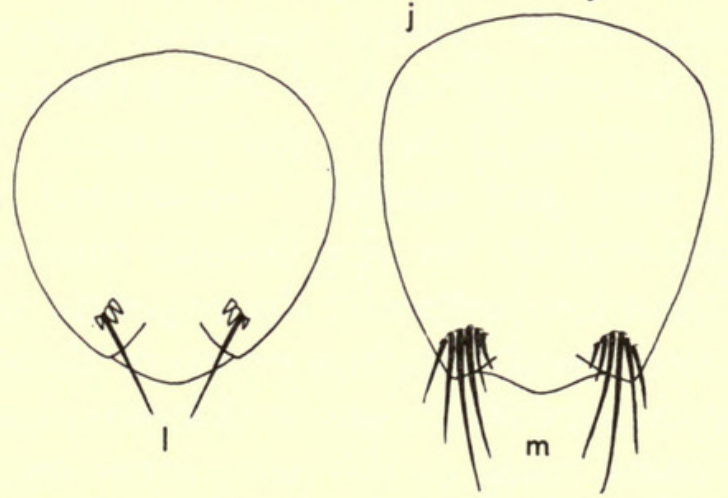


Wales. (b) Male gnathopod I, $2.9 \mathrm{~mm}$. $\widehat{\delta}$, Swansea, Wales. (c) Male gnathopod I, $3.9 \mathrm{~mm}$. đ. Swansea, Wales. (g) Male gnathopod 2, Swansea, Wales. (m) Male telson, Swansea, Wales. Microdeutopus stations Della Vile. (d) Male gnathopod I, I.9 mm. o. Naples, Italy. (e) Male gnathopod I, $2 \cdot 0 \mathrm{~mm}$. of $^{*}$ Naples, Italy. (f) Male gnathopod

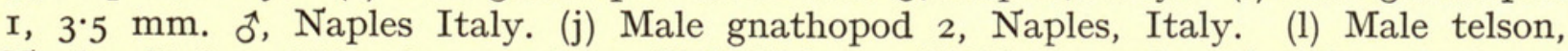
Naples, Italy. Microdeutopus haswelli Stabbing. (h) Male gnathopod 2, Port Jackson, Australia (Holotype). Microdeutopus versiculatus (Bate). (i) Male gnathopod 2, Plymouth, Devon. (k) Male gnathopod I, Plymouth, Devon. 
algae, especially cystoseires and corallines, polyzoans, Mytilus etc. in areas of high detritus accumulation.

Distribution. Along the south and west coasts of the British Isles to the Shetlands, in the Channel Islands and the adjoining French coast, Bay of Biscay (Houat, Arcachon), the Atlantic coasts of Spain and Portugal, Senegal and the Azores. Also around the coasts of the Mediterranean, Tyrrhenian and Adriatic seas, and in the Black sea (north-east of Cape Caliacra, Roumania).

\section{Microdeutopus stationis Della Valle}

(Text-figs. 2d, f, 3d-f, j, 1, 4a, 5c, 6e-f, 2oe)

Microdeutopus gryllotalpa Nebeski, r880 : 45, fig. 4I.

Microdeutopus stationis Della Valle, I893 : 4I5, pl. 5, fig. 2, pl. Io, figs. 3I-4I ; Stebbing, I906 : 590; Norman, I907 : 368, pl. I6, fig. 4, pl. I7, figs. 8-I I ; Chevreux \& Fage, I925 : 300, fig. 3I I; Cecchini \& Parenzan, I934 : 216, fig. 44; Miloslavskaia, I939a : I22; Gurjanova, I951 : 832, fig. 58I ; Barnard, I958 : 29.

[Non] Microdeutopus stationis Sowinsky, 1895:237, pl. 4, figs. I-5; Sowinsky, I898:48o.

TyPE OF LOCALITy. Naples, Italy.

Diagnosis of male. Antenmule about equal to the body length, the first peduncular article slightly shorter than the second, the third less than one third the length of the second; flagellum twice the length of the peduncle, normally with up to twenty-six articles (maximum recorded twenty-nine); accessory flagellum with two to five articles, the terminal article rudimentary. Antenna two thirds the length of the antennule, the fourth and fifth peduncular articles subequal; flagellum equal in length to the fifth peduncular article, normally with up to twelve articles (maximum recorded fourteen). Peraeon segments 2-4 each with a process in the mid-ventral line, that of segment 2 slender spiniform, straight, those of segments 3 and 4 becoming progressively shorter and more robust. Gnathopod I with article I strongly produced anteriorly, very attenuated; article 2 scarcely expanded; article 5 very enlarged, longer than broad, the posterior distal angle produced into three teeth of which the central is the longest, the inner two slightly recurved; article 6 short, the posterior margin convex distally, concave basally; article 7 long and slender. Gnathopod 2 with article 2 not expanded; article 5 longer and slightly broader distally than article 6 . Uropod 3 with the rami slightly shorter than the peduncle, the expodite slightly the longer of the two rami, bearing on its outer distal margin a group of three closely associated elongate spines, with a pair of spines (of which one is elongate) basal to these and not infrequently a further solitary spine basal to the pair; inner margin of exopodite with one or two solitary spines; endopodite outer margin with a pair of spines, basal to which is a solitary spine; inner margin with up to two pairs of spines and a solitary spine; terminal spines and setae of both rami very short. Telson with each terminal crest bearing on its distal dorsal margin, a group of three short stout spines and a single fine seta.

Maximum size of male: Io $\mathrm{mm}$.

Female. As the male, except for the structure of the sexually dimorphic gnathopoda, and absence of ventral peraeon processes. Gnathopod I with article 2 scarcely 

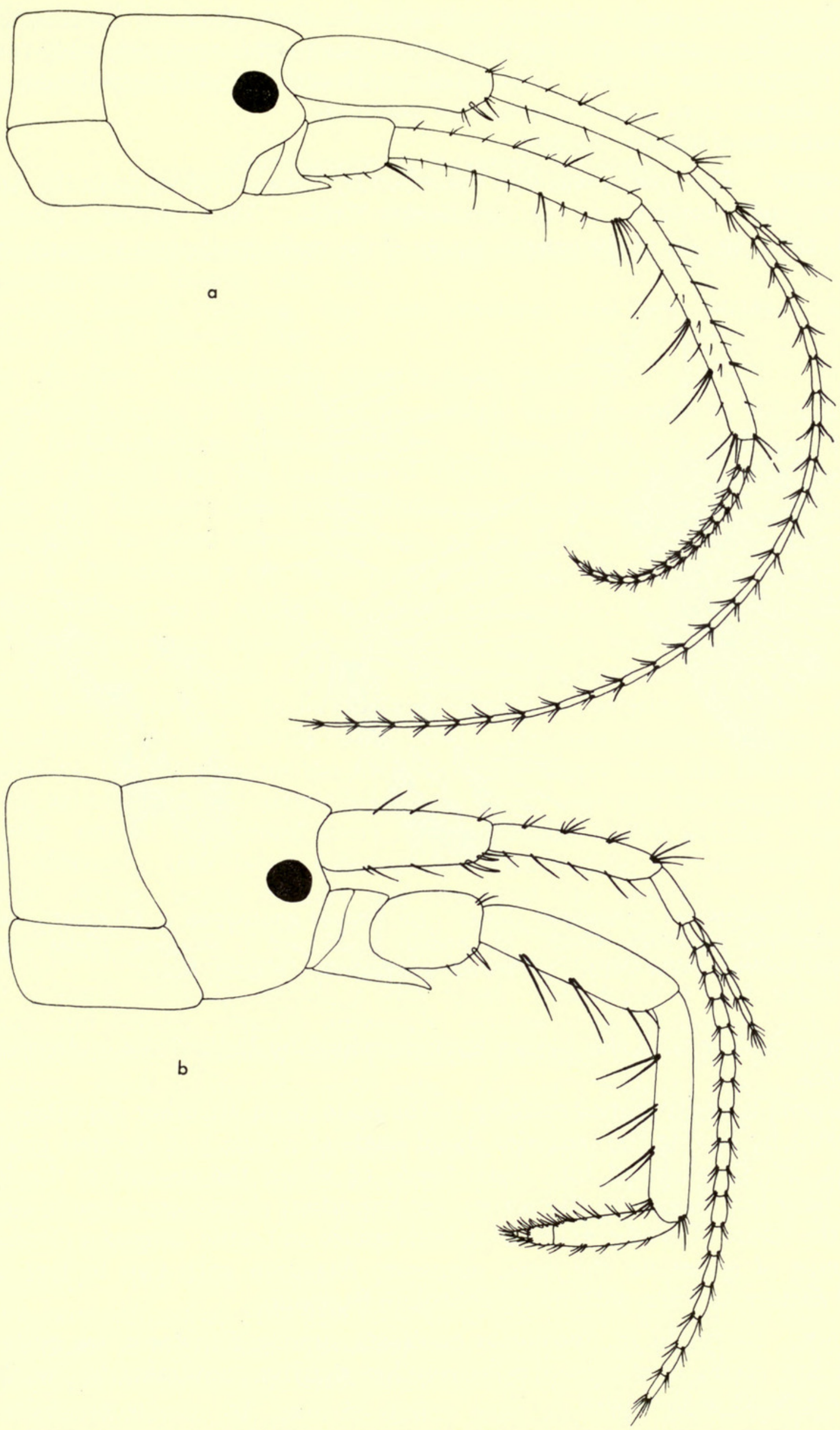

FIG. 4. Microdeutopus stationis Della Valle. (a) Male head, St. Peter's Port, Guernsey. Microdeutopus haswelli Stebbing. (b) Male head, Port Jackson, Australia (Holotype). 
expanded, articles 5 and 6 subequal in length, the sixth distinctly broader distally, narrowing at the junction with the fifth article, the palmar angle smoothly rounded; article 7 elongate and slender. Gnathopod 2 with article 2 relatively slender, article 5 slightly shorter than article 6 , setae not pectinate.

Maximum size of female : $\mathrm{I} 2 \mathrm{~mm}$.

Discussion. The species was first described by Nebeski (I880) from the Adriatic, and erroneously ascribed to $M$. gryllotalpa Costa. That author's illustrations (Nebeski, I880, fig. 4I) of the growth stages of the male gnathopod I clearly indicate

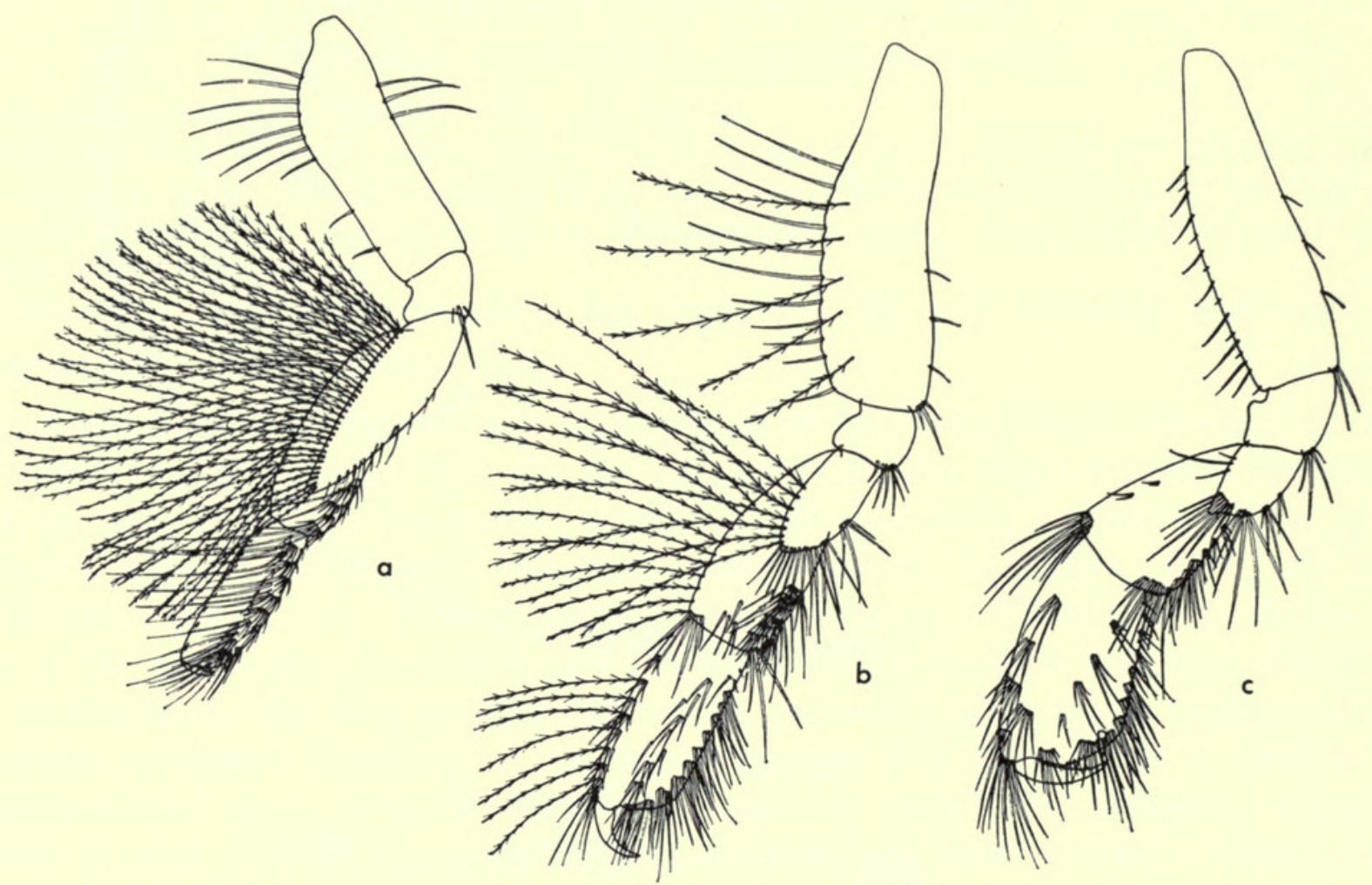

FIG. 5. Microdeutopus versiculatus (Bate). (a) Female gnathopod 2, Plymouth, Devon. Microdeutopus gryllotalpa Costa. (b) Female gnathopod 2, Swansea, Wales. Microdeutopos stationis Della Valle. (c) Female gnathopod 2, Naples, Italy.

that he was dealing with the species later described by Della Valle under the name M. stationis.

$M$. stationis is easily distinguishable in the male from all other described species in the genus by having the posterior distal angle of article 5 of the first gnathopod (Text-figs. 2d, f) produced into three teeth, of which the central is the longest. Females have few diagnostic characters, but important characters taken in combination are the telson (Text-fig. 3I) bearing both spines and setae, uropod 3 (Text-fig. 6f) with groups of spines on the rami, accessory flagellum with two to four articles and long slender antenna with multi-articulate flagellum.

Ecology. Recorded in Sacchoriza holdfasts, among Posidonia, on oyster beds and over fine sands, in regions of relatively low detritus contamination, in the sublittoral to a depth of 50 metres. 
Distribution. Guernsey (St. Peter's Port), France (Arcachon, Roscoff, Perros Guirec), Corsica (Ajaccio, Bonifacio), Algeria (Bône, La Calle), Tunisia (Golfe de Gabes), Italy (Naples, Trieste), Greece (Khios).

\section{Microdeutopus haswelli Stebbing}

(Text-figs. 2e, 3h, 4b)

Microdeuteropus chelifer Hasell, I879: 340, pl. 22, fig. 3; Della Valle, I893 : 42I.

Microdeutopus chelifer Haswell, I882: 265.

Microdeutopus haswelli Stebbing, I899:350; Stebbing, I906:591; Stebbing, I910:647; Sheard, I937 : 26; Barnard, I958: 29.

Type Locality. Clark Island, Port Jackson, Australia.

The present species is represented by a single male specimen in Haswell's collections, at the Australian Museum, Sydney. Haswell did not designate types for any of his material, but this specimen is almost certainly the holotype, agreeing in the main with Haswell's description, and is here considered as such. An expanded description of the more relevant features of the holotype is given. The range of variation of this species is not known, as further material has not been forthcoming.

Description of male holotype. Head lateral lobes slightly produced, obtuse; eyes round. Antennule slightly less than half the body length, the first and second peduncular articles subequal, the third slightly over a third the length of the second; flagellum longer than the peduncle, with seventeen articles; accessory flagellum with five articles, the fifth article rudimentary. Antenna shorter than the antennule, sub-pediform, the fifth peduncular article slightly longer than the fourth; flagellum with four articles, the first article long and robust, over half the length of the fifth peduncular article, the second short, the third and fourth articles progressively shorter, obscurely articulate. Gnathopod I with article I moderately produced anteriorly, obtuse; article 2 short and expanded, the anterior margin excavate; article 5 much enlarged, longer than broad, the posterior distal angle produced into two teeth, of which the outer is the longer and recurved; article 6 short, the posterior margin concave centrally; article 7 very stout. Gnathopod 2 with article 2 very elongated and slender, concave anteriorly, articles 5 and 6 slender with article 5 slightly the longer. Epimeral plate 3 with the posterior free corner produced into a tooth, above which is inserted a short seta. Uropod 3 with the peduncle exceeding the length of the very short and stout rami, of which the exopodite is very slightly the longer; each ramus with a terminal group of setae which exceed the length of the ramus. Telson with the terminal crests moderately well developed, each bearing on its distal, dorsal margin, a group of three setae, of which the central is the longest.

Length : $4.5 \mathrm{~mm}$.

Discussion. The very robust, sub-pediform antenna, (Text-fig. $4 \mathrm{~b})$ with the flagellum very reduced and the first flagellar article robust, approaches the condition found in many Corophiidae. However, the lateral compression of the urosome, biramous third uropoda, and moderately well developed coxae, are characteristic of aorid/photid stock. M. haswelli differs from all other Microdentopus species, 
except $M$. sporadhi sp. nov. (p. I36), in having the posterior distal angle of article 5 of the male first gnathopod (Text-fig. 2e) produced into two teeth, of which the outer is the longer. The elongated, slender article 2 of the male second gnathopod (Textfig. $3 \mathrm{~h}$ ) is also a distinctive feature.

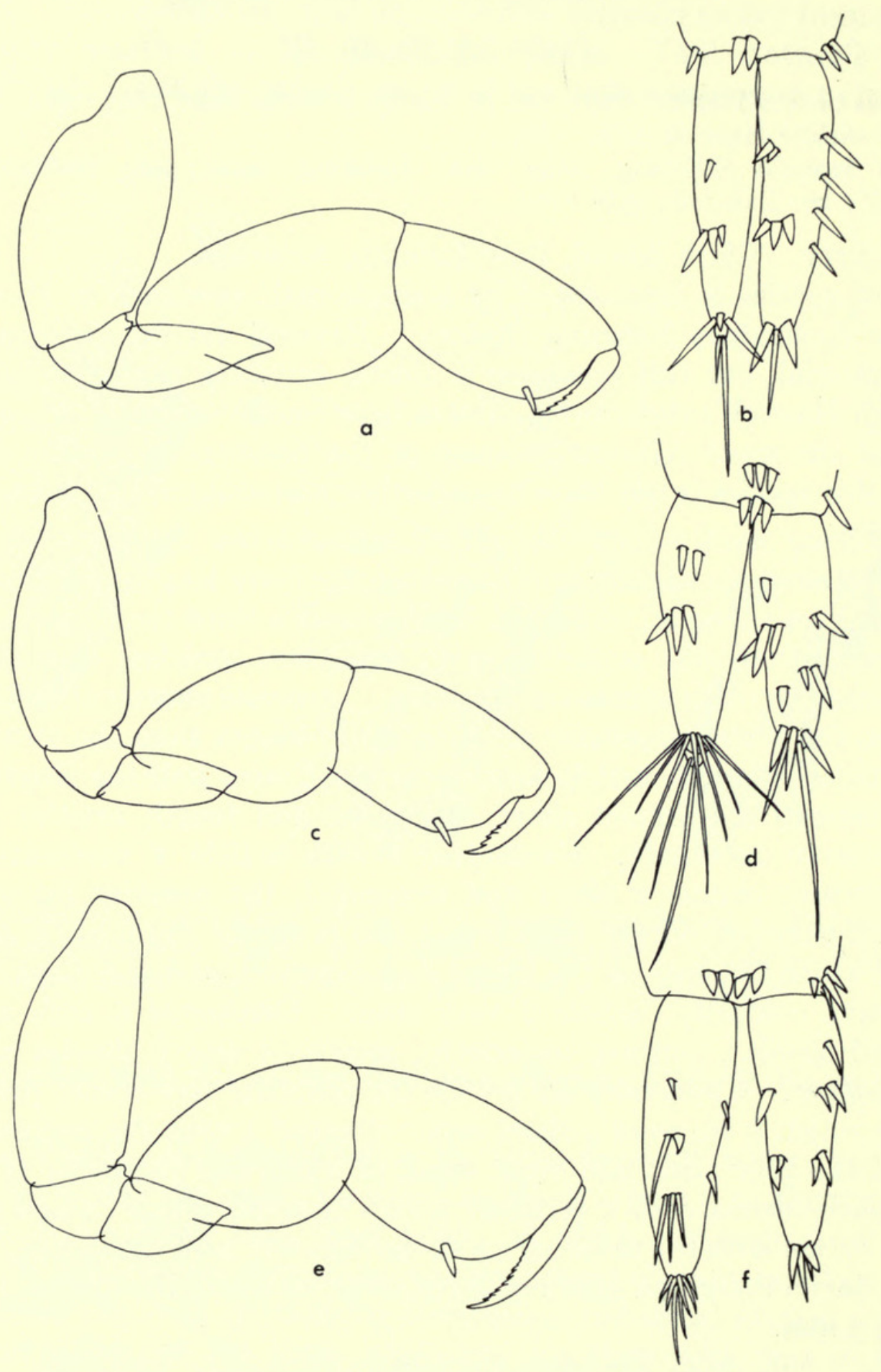

Fig. 6. Microdeutopus versiculatus (Bate). (a) Female gnathopod I, Plymouth, Devon. (b) Male uropod 3, Falmouth, Cornwall. Microdeutopus gryllotalpa Costa. (c) Female gnathopod I, Swansea, Wales. (d) Male uropod 3, Arcachon, France. Microdeutopus stationis Della Valle. (e) Female gnathopod I, Naples, Italy. (f) Male uropod 3, Naples, Italy. 
Ecology. Unknown.

Distribution. Not yet recorded from other than the type locality.

\section{The " ANOMALUS " GROUP OF SPECIES}

The systematics of the anomalus group of species has long been under dispute. In I856 Bate erected two species, Lembos damnoniensis and L. cambriensis, but gave no descriptions and only in the following year attributed to the former species " first hand with a thumb on carpus " to the latter " first hand without thumb". White (I857), no doubt in error, transposed the " $\mathrm{mn}$ " in L. damnoniensis, to " $\mathrm{nm}$ " in L. danmoniensis, and later Bate (I862) and Bate and Westwood (I863) relegated $L$. cambriensis to a synonym of $M$. anomalus (Rathke) and $L$. damnoniensis to a synonym of $M$. gryllotalpa Costa. Norman (I868) considered that $M$. gryllotalpa Bate represented a young male $M$. anomalus, but later (Norman I905b) decided that $M$.damnoniensis Bate, was a distinct species, and that $M$. gryllotalpa Bate (non M. gryllotalpa Costa) represented that species. Sars (I894) figures a species under the name $M$. propinquus Sars, but in the text relegates it to a synonym of $M$. danmoniensis (Bate) (altered presumably in error, or following White, I857, from $M$. damnoniensis). Stebbing (I906) considered that $M$. propinquus Sars was not synonymous with $M$. damnoniensis (Bate) and reinstated it as a distinct species with synonym $M$. danmoniensis Sars (non $M$. damnoniensis (Bate)). Andersson (I954) considered $M$. propinquus Sars to be a juvenile form of $M$. anomalus (Rathke) and in the synonymy also listed L. damnoniensis Bate. Della Valle (I893) described a new species $M$. algicola, and placed $M$. damnoniensis in the synonymy of $M$. anomalus (Rathke).

Present investigations suggest that there are three distinct species in the "anomalus" group; M. anomalus (Rathke), M. damnoniensis (Bate) and M. algicola Della Valle.

Males of the "anomalus" group of species are distinguished from those of all other Microdeutopus species, except $M$. versiculatus (Bate) $M$. chelifer (Bate) and $M$. armatus Chevreux by having the posterior margin of gnathopod I produced into a single marginal tooth. In $M$. anomalus an accessory tooth is usually present, but this always arises within the posterior margin. They differ from the above three species in the structure of gnathopod 2, which is neither chelate as in $M$. chelifer and $M$. armatus not densely setose as in $M$. versiculatus. Females of the "anomalus" group of species are notable for their lack of diagnostic features, and are therefore identifiable only by negative characters. They are distinguishable from $M$. versiculatus, $M$. gryllotalpa and $M$. stationis by the absence of paired spines from the rami of the third uropod, from the first two species by the absence of pectinate setae on gnathopod 2. They differ also from $M$. stationis and from the "schmitti" group of species by the lack of any spines as distinct from setae on the telson terminal crests, and from $M$. armatus by the lack of any pronounced projection at the anterodistal corner of article 2 or gnathopod 2. Within the " anomalus" group of species the identification of females is even more difficult, particularly in the absence of males. In practice, when two or more of the "anomalus" group occur together 
in a sample, the females have been separated with some degree of accuracy and grouped together with the corresponding males, according to characters summarized in Table I. Owing to confusion between the three species, records are unreliable and so the ecology and distribution of the "anomalus" group of species is poorly known.

\section{Character}

I. Maximum size

2. Antennule

a. Ratio of peduncular articles

b. Average number of flagellar articles

c. Number of articles to accessory flagellum excluding vestigial terminal article

3. Uropod 3
a. Peduncle

b. rami

\section{M. anomalus}

Io $\mathrm{mm}$.

$$
\text { I : I } \frac{1}{3}: \frac{1}{2}
$$

23

3-4

Flanges poorly developed, dorsal and inner longest slender, elongate

\section{M. damnoniensis}

$4^{\cdot} 5 \mathrm{~mm}$.

I $:$ I $: \frac{1}{2}$

I4

I

Flanges well developed inner much the longest broad, robust
M. algicola $4^{\circ} 5 \mathrm{~mm}$. I : I : $\frac{1}{3} *$ $20^{*}$

2

as damnoniensis

as anomalus

TABLE I. The main identification characters for females of the "anomalus" group of species. $*$ = From Della Valle (1893).

\section{Microdeutopus anomalus (Rathke)}

$$
\text { (Text-figs. 7a, 8a-e, 9c, e, Ioc, f, 2ob, d) }
$$

Gammarus anomalus Rathke, I843:63, pl. 4, fig. 7; Lilljeborg, I855: 457 .

A utonoe anomala (Rathke) Bruzelius, I859:25, fig. 4.

Autonoe sp. Smith, I874:562.

Microdeutopus anomalus (Rathke) Boeck, I870 : I57; Catta, I875: 167; Boeck, I876:567, pl. 25, fig. 5; Della Valle, I893 : 4I7, pl. 56, fig. 4I ; Sars, I894 : 54O, pl. I9I ; Sowinsky, I898 : 48o, pl. Io, figs. 20-24; Stebbing, I906 : 591; Kunkel, I910 : 76, fig. 29; Chevreux \& Fage, I925 : 298, fig. 309; Stephensen, 1927 : I24; Stephensen, I929a : I52, fig. 275; Oldevig, I933 : 212, fig. 94; Miloslavskaia, I939a: I23; Carausu \& Carausu, I942 : 74, fig. 5; Schellenberg, I942 : I88, fig. I 55; Soika, I949: I98; Gurjanova, I951 : 833, fig. 582; Andersson, I954 : 252, figs. I-4; Barnard, I958 : 29.

[Non] Microdeutopus anomalus Bate, r862: 164, pl. 30, fig. 3.

Microdeuteropus anomalus (Rathke) Norman, I869a : 28I ; Norman, I886 : I6.

Microdeutopus propinquus Sars, I894:542, pl. 192; Stebbing, I906: 592; Stephensen, I927: I 25; Stephensen, I929a : I52, fig. 274; Oedevig, I933 : 212, fig. 95; Schellenberg, I942 : I89, fig. I56; Dahl, I946 : 5; Gurjanova, I951 : 834, fig. 583 .

Microdeutopus danmoniensis [sic] Sars, I894:542, pl. I92.

Microdeutopus stationis Sowinsky, I895:237, pl. 4, figs. I-6.

Type locality. Christiansund, Norway. 
Diagnosis of male. Antennule about two thirds the body length, the first peduncular article shorter than the second, the third about one third the length of the second; flagellum slightly less than twice the length of the peduncle, normally with up to twenty-three articles (maximum recorded twenty-seven); accessory flagellum with four to five articles, the terminal article of which is rudimentary. Antenna two thirds the length of the antennule, the fourth and fifth peduncular articles subequal; flagellum about equal to the fifth peduncular article, normally with up to six articles (maximum recorded eight). Peraeon segments $2-4$ each with a spine in the mid-ventral line, those of segments 2 and 3 the longest and most slender, that of segment 4 the shortest and most robust; segment 5 in some specimens with a vestigial spine. Gnathopod I with article I strongly produced anteriorly, very attenuated; article 2 elongate and relatively slender; article 5 very enlarged, longer than broad, the posterior distal angle produced into a straight or slightly recurved tooth, at the base of which in mature specimens is characteristically an accessory tooth, which arises within the posterior margin and is not an extension of it as in other Microdeutopus species; article 6 with the posterior margin concave, excepting the palmar angle; article 7 variable, usually relatively long and slender. The accessory tooth on article 5 varies considerably in size, sometimes being so reduced that it does not project over the posterior margin and appears obsolete; occasionally in adults and frequently in juveniles it is absent. The aberrant form of this species described and figured by Chevreux and Fage (I925) with two accessory teeth, has not been observed in the present investigations. Gnathopod 2 with article 2 unexpanded; articles 5 and 6 elongate, 5 slightly the broader; article 6 almost three times as long as broad, with the palmar angle oblique; article 7 relatively long. Uropod 3 with the peduncle slender, its outer, inner and dorsal margins each produced into a flange of which the dorsal and inner are the most pronounced; rami equal to or slightly exceeding the length of the peduncle; endopodite slightly shorter than the exopodite, with four spines on the inner margin and two on the outer, none of which are closely associated; exopodite with two spines on the outer margin only. Telson, with each terminal crest bearing on its distal dorsal margin, a pair of unequal setae.

Maximum size of male : $8 \mathrm{~mm}$.

Female, As the male, except for the structure of the sexually dimorphic gnathopoda, and absence of ventral peraeon spines. Gnathopod I with article I somewhat produced anteriorly, rounded; article 2 unexpanded; article 6 longer than article 5, distinctly broader distally, and constricted at the junction with article 5; article 7 longer than the palmar region. Gnathopod 2 with article 2 elongate and slender; article 6 considerably longer and more slender than article 5 .

Maximum size of female : $10 \mathrm{~mm}$.

Discussion. M. anomalus is distinguishable in the male, in its typical form, from all other Microdeutopus spp. by the presence of an accessory tooth, arising within the posterior margin of article 5 of gnathopod I (Text-figs. 8a, b, d, e). Past workers have described $M$. anomalus as having this accessory tooth (or teeth) always present, although this is by no means the case, particularly in immature material, and have frequently utilized this character as a basis for a key (Stebbing, I906, Chevreux \& 

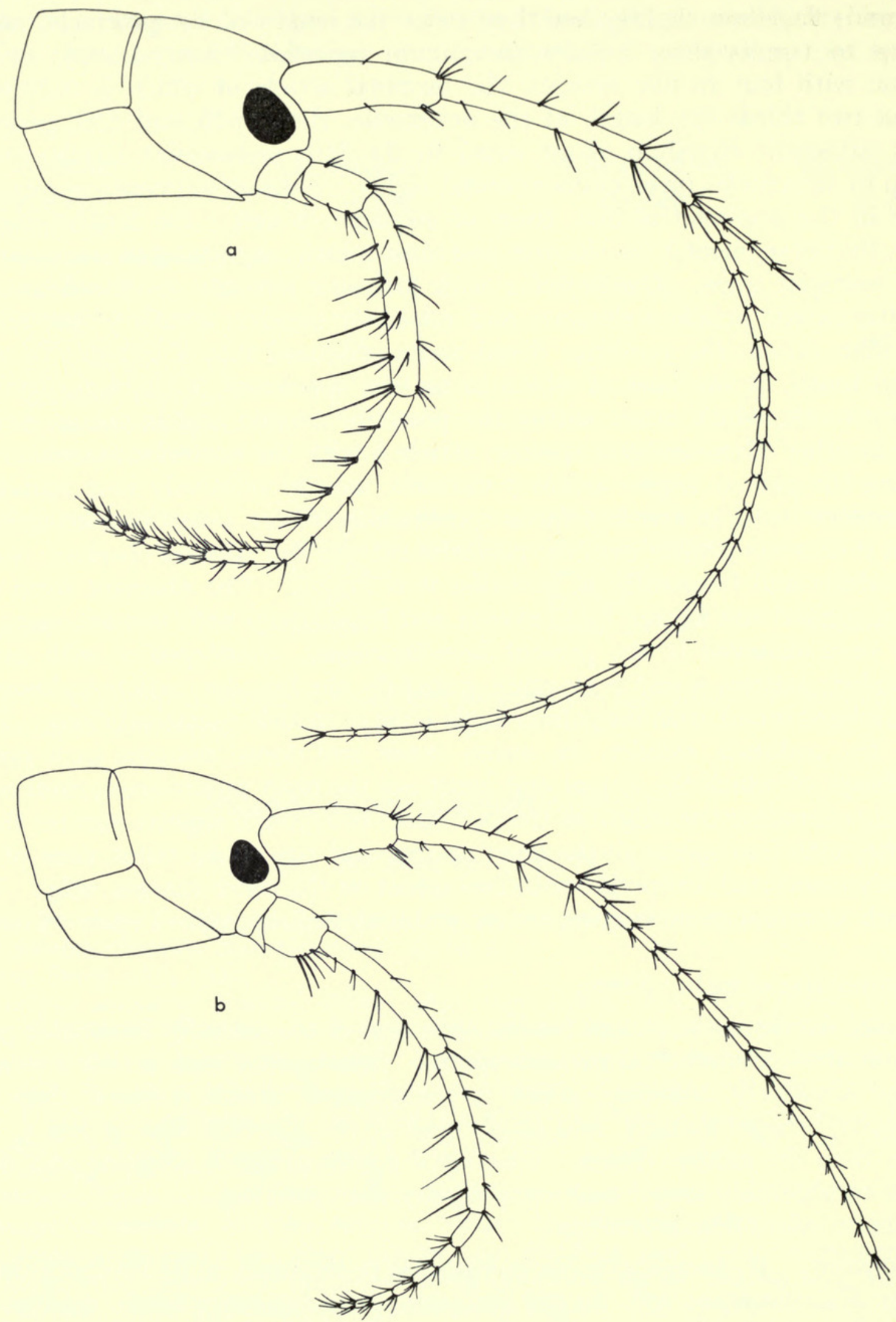

Fig. 7. Microdeutopus anomalus (Rathke). (a) Male head, Plymouth, Devon. Microdeutopus damnoniensis (Bate). (b) Male head, Plymouth, Devon. 


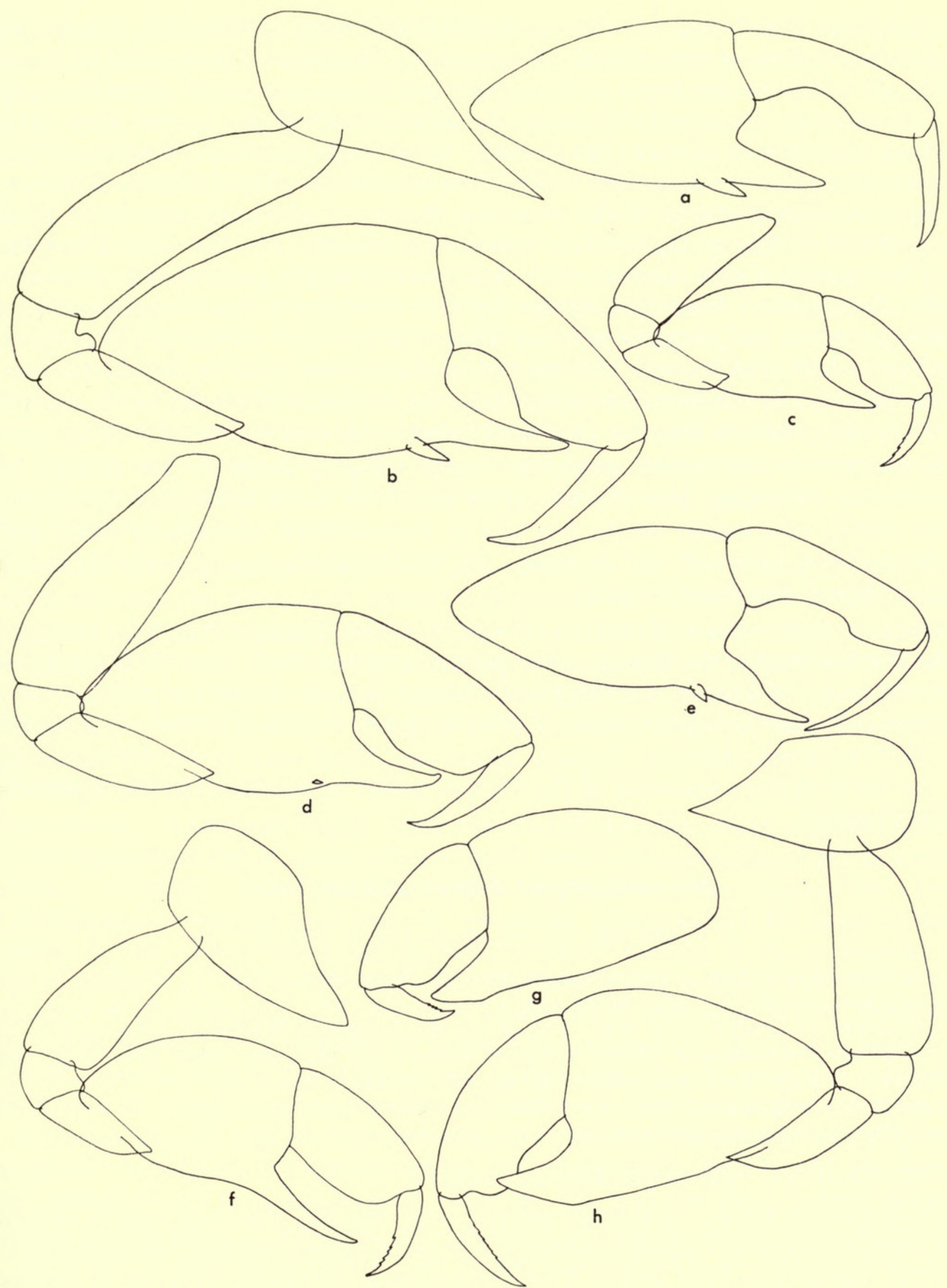

Fig. 8. Microdeutopus anomalus (Rathke). (a) Male gnathopod I, Falmouth, Cornwall. (b) Male gnathopod I, Bonifacio, Corsica. (c) Male gnathopod I, Falmouth, Cornwall. (d) Male gnathopod I, Isle of Mull, Scotland. (e) Male gnathopod I, Isle of Mull, Scotland. Microdeutopus damnoniensis (Bate). (f) Male gnathopod I, Plymouth, Devon. Microdeutopus algicola Della Valle. (g) Male gnathopod I, Naples, Italy. (h) Male gnathopod I, Bône, Algeria. 
Fage, I925). This has often led to the attributing of immature material of the present species to $M$. damnoniensis (Bate), the separation of which must be made with great care. In its immature form, or in mature specimens lacking an accessory tooth, $M$. anomalus is distinguishable from $M$. algicola Della Valle by the form of the primary tooth which arises at the posterior distal angle of article 5 and is relatively slender, though never as slender as in $M$. damnoniensis. In $M$. algicola (Text-figs, $8 \mathrm{~g}-\mathrm{h}$ ) a considerable area of the posterior margin of article 5 contributes to the development of the tooth, which is hence very robust. $M$. anomalus differs from $M$. damnoniensis also in the form of the tooth on article 5 of gnathopod $\mathrm{I}$, but is more easily distinguished from that species by the structure of the second gnathopod, which is slender and elongate with an oblique palm in $M$. anomalus (Text-fig. 9c), relatively short and broad, with an almost transverse palm in $M$. damnoniensis (Text-fig. 9a). In addition, the rami of uropod 3 are long and slender in M. anomalus (Text-fig. 9e), whereas they are short and broad in $M$. damnoniensis (Text-fig. 9g).

Ecology. A sub-littoral species in depths ranging down to 200 metres, but occasionally extending into the intertidal zone. In areas influenced by detritus, often among arborescent weeds, but also in Zostera beds, and among shells, polyzoans, sponges, tunicates and Mytilus. In the Black Sea, associated with Modiola phaseolina and Amphiura florifera.

Distribution. Norway south of the Lofoten Islands, Sweden, Denmark, including the Baltic, the British Isles, particularly the South and West coasts, the channel coasts of France, including the Channel Islands, along the Atlantic coasts of France, Spain, Portugal and North West Africa to the Canary Isles. Throughout the Mediterranean, Adriatic, Aegean, Ionian and Black seas, in the Bermudas and on the north-eastern seaboard of the United States of America (Rhode Island and Massachusetts).

\section{Microdeutopus damnoniensis (Bate)}

(Text-figs. 7b, 8f, 9a, g, Ioa-b, 2oh, j)

Lembos damnoniensis Bate, I856 (nomen nudum): 58; Bate, I857 : I42.

Lembos danmoniensis [sic] (Bate) White, I857 : 180.

Microdeutopus gryllotalpa Bate, I862 : 163, pl. 30, fig. I; Bate \& Westwood, I863 : 289.

Microdeutopus damnoniensis (Bate) Norman, I905a : 24; Stebbing, I906 (pro-parte) : 593;

Chevreux \& Fage, I925 (pro-parte): 297, fig. 308; Barnard, I958 : 29.

Microdeutopus danmoniensis [sic] (Bate) Norman \& Scott, I906:83.

[Non] Microdeutopus danmoniensis [sic] Sars, I894:542, pl. I92.

Type locality. Plymouth, Devon, England.

Diagnosis of male. Antennule slightly over one half the body length, the first and second peduncular articles subequal, the third almost one half the length of the second; flagellum a little longer than the peduncle, normally with up to fourteen articles (maximum recorded fifteen); accessory flagellum with two articles the terminal article rudimentary. Antenna shorter than the antennule, the fourth and fifth peduncular articles subequal; flagellum about equal to the fifth peduncular article normally with up to seven articles (maximum recorded eight). Peraeon 
segments 2-4 each with an anteriorly directed spine in the mid-ventral line, that of segment 2 the longest. Gnathopod I with article I moderately produced anteriorly, less acute than in $M$. anomalus or $M$. algicola; article 2 expanded somewhat distally; article 5 very enlarged, longer than broad, the posterior distal angle produced into a single, long, slender, inward curved tooth which in fully mature specimens considerably exceeds half the length of article 6 ; article 6 with the posterior margin smoothly rounded; article 7 relatively long with accessory teeth on the posterior margin. Gnathopod 2 with article 2 expanded; articles 5 and 6 short, 5 slightly the longer, but scarcely broader than article 6 , which is scarcely twice as long as broad, and has the palmar angle almost transverse; article 7 short and robust. Uropod 3 having the peduncle with its lateral and dorsal flanges very distinct, as in $M$. algicola; rami short and very stout, not exceeding the length of the peduncle, the exopodite the longer of the two rami, with two separated spines on the outer margin, the more distal of which is much the longer, endopodite with a single median spine on the outer margin, and a single more distal spine on the inner, each ramus terminating in a group of spines of which one is relatively long. Telson as M. anomalus.

Maximum size of male : $4.5 \mathrm{~mm}$.

Female. As the male, except for the structure of the sexually dimorphic gnathopoda, and the absence of ventral peraeon spines. Gnathopod I with article I not markedly produced anteriorly, very obtuse; article 2 somewhat expanded; article 6 slightly longer than article 5 and narrowing somewhat at the junction with it; article 7 longer than the palmar region. Gnathopod 2 with article 2 unexpanded and article 6 somewhat longer and more slender than article 5, with the palmar margin angular.

Maximum size of female : $4.5 \mathrm{~mm}$.

Discussion. Andersson (I954) using material of Swedish origin concluded that $M$. propinquus Sars and $M$. damnoniensis (Bate) were both synonyms of $M$. anomalus (Rathke). Present investigations, whilst supporting the contention that $M$. propinquus is synonymous with $M$. anomalus, indicate that $M$. damnoniensis certainly is not. Since there are no substantiated records of $M$. damnoniensis north of latitude $5 \mathrm{I}^{\circ} \mathrm{N}$. it is probable that Andersson was working entirely with a population of $M$. anomalus. The distinction between $M$. anomalus and $M$. damnoniensis is not simply one of presence or absence of an accessory tooth, and most socalled $M$. damnoniensis in the literature are in fact immature $M$. anomalus. Nevertheless, true $M$. damnoniensis does exist and males are distinguishable from those of $M$. anomalus and $M$. algicola by a number of important characters, including the very slender, inward curved tooth on article 5 of gnathopod I (Text-fig. 8f), the short, broad articles 5 and 6 of gnathopod 2 (Text-fig. 9a), and the short, robust uropod 3 rami (Text-fig. 9g). In addition, the number of articles to the accessory flagellum of the antennule remains constant from eclosion to maturity, in contrast with the condition in $M$. anomalus where the number of articles increases with age.

Ecology. Unlike $M$. anomalus, the present species occurs most commonly in the intertidal zone, among sponges, polyzoans and corallines, especially in rock pools, or in the shallow sub-littoral. 


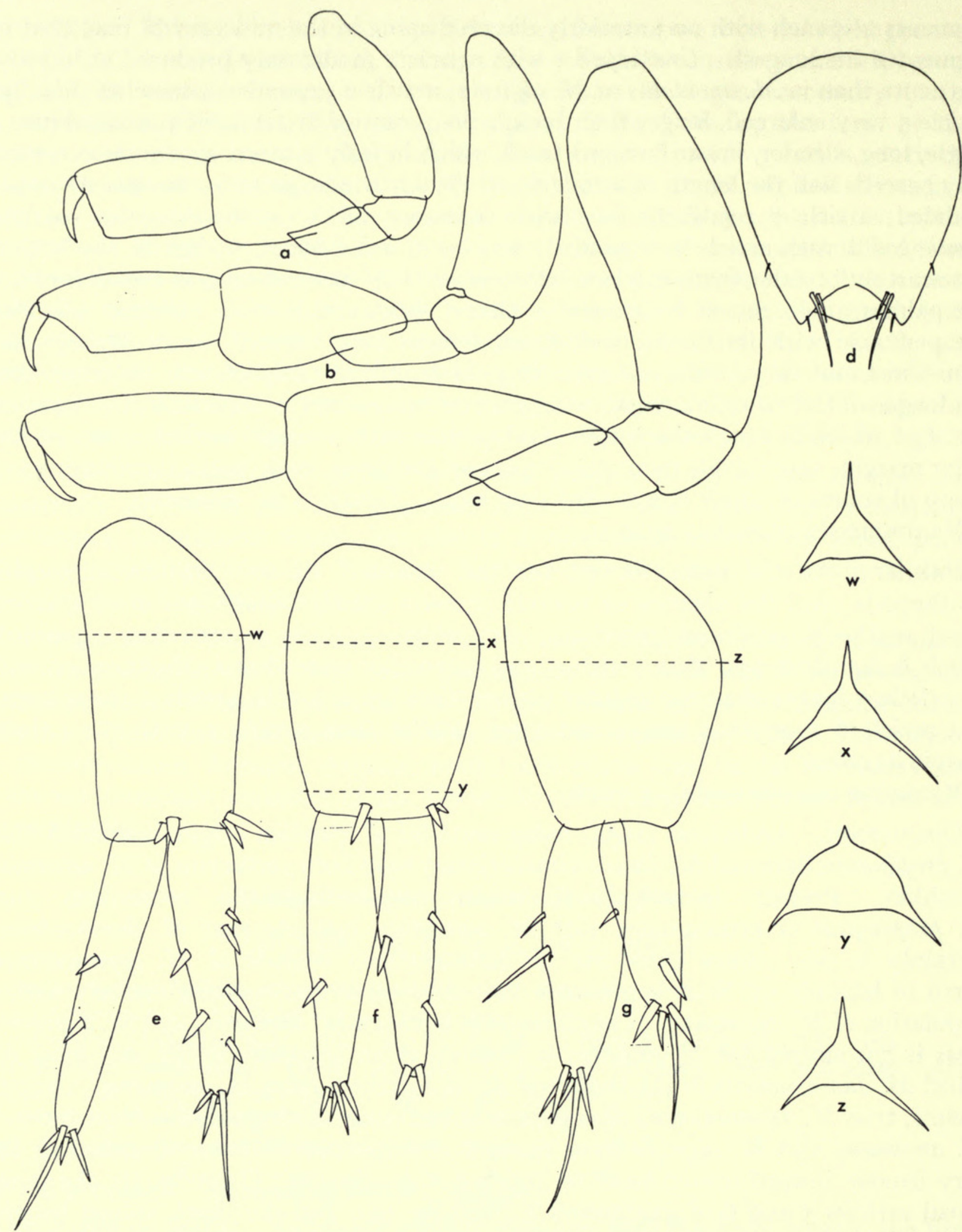

FIG. 9. Microdeutopus damnoniensis (Bate). (a) Male gnathopod 2, Plymouth, Devon. (g) Male uropod 3, with transverse section across peduncle at $z$, Plymouth, Devon. Microdeutopus algicola Della Valle. (b) Male gnathopod 2, Naples, Italy. (d) Male telson, Naples, Italy. (f) Male uropod 3, with transverse sections across peduncle at $\mathrm{x}$ and $\mathrm{y}$, Naples, Italy. Microdeutopus anomalus (Rathke). (c) Male gnathopod 2, Plymouth, Devon. (e) Male uropod 3, with transverse section across peduncle at w, Plymouth, Devon. 
Distribution. Very difficult to ascertain, due to confusion in the literature with immature $M$. anomalus. Present investigations have confirmed material from Drake's Island and Wembury Bay, Plymouth, Jersey and Guernsey, and Bandol, France.

Type Material. A lectotype has been erected from Bate's syntypic series (see Appendix 2).

\section{Microdeutopus algicola Della Valle}

(Text-figs. 8g-h, 9b, d, f, Iod-e, 2of)

[?] Microdeutopus grillotalpa Sowinsky, I880: I25, pl. 5, fig. I7a-d.

Microdeutopus algicola Della Valle, I893 : 418, pl. I, fig. 3, pl. II, figs. I-I2; Norman, I905a : 25 .

Microdeutopus damnoniensis (Bate) Stebbing, 1906 (pro-parte): 593; Chevreux \& Fage, 1925 (pro-parte): 297, fig. 308; [?] Miloslavskaia, 1939a : I24, fig. 24; [?] Soika, I949 : 199, [?] Gurjanova, I95 I : 834, fig. 584 .

Type Locality. Mergellina, Naples, Italy.

Diagnosis of male. Antennules and antennae have been missing in material examined in present investigations, and the description of these appendages here is extracted from the description and figures of Della Valle (I893). Antennules with the first and second peduncular articles sub-equal, the third about one third the length of the second; flagellum longer than the peduncle with twenty articles; accessory flagellum possibly with two articles, but almost certainly three, of which the terminal is rudimentary as figured (for $M$. grillotalpa) by Sowinsky (I880). Antenna shorter than the antennule, the fourth peduncular article slightly longer and more robust than the fifth, flagellum about equal to the fifth peduncular article, with eight articles. Peraeon segments 2-4 each with an anteriorly directed spine in the mid-ventral line, that of segment 2 the longest; segment 5 with a vestigial spine. Gnathopod I with article I moderately produced anteriorly, acute, though less attenuated than in $M$. anomalus; article 2 relatively robust, expanded somewhat distally; article 5 very enlarged, the posterior margin produced into a single, robust, broad based tooth not exceeding half the length of article 6 ; article 6 with the posterior margin convex distally, straight or slightly concave basally; article 7 robust, with accessory teeth on the posterior margin. Gnathopod 2 with article 2 having the anterior margin produced into a flange which terminates distally in a blunt process; articles 5 and 6 slender, subequal in length, article 5 slightly the broader; article 6 over twice as long as broad, with the palmar region oblique; article 7 short and robust. Uropod 3 with the peduncle broad, due to the marked development of the lateral flanges, particularly the inner, which exceeds in length both the outer flange and the dorsal crest; rami long and slender, about equal in length to the peduncle, the exopodite slightly the longer, not differing in spination from $M$. anomalus of a similar size. Telson as in M. anomalus.

Maximum size of male : $4.5 \mathrm{~mm}$.

Female. As the male, except for the structure of the sexually dimorphic gnathopoda, and absence of ventral peraeon spines. Gnathopod I with article I not markedly produced anteriorly, obtuse; article 2 robust, otherwise scarcely differing 
from that of $M$. damnoniensis. Gnathopod 2 with article 6 having the palmar angle rounded, otherwise as that of $M$. damnoniensis.

Maximum size of female $4.5 \mathrm{~mm}$.

Discussion. M. algicola is the most robust member of the "anomalus" group of species. In facies it more closely resembles $M$. stationis, than it does $M$. anomalus

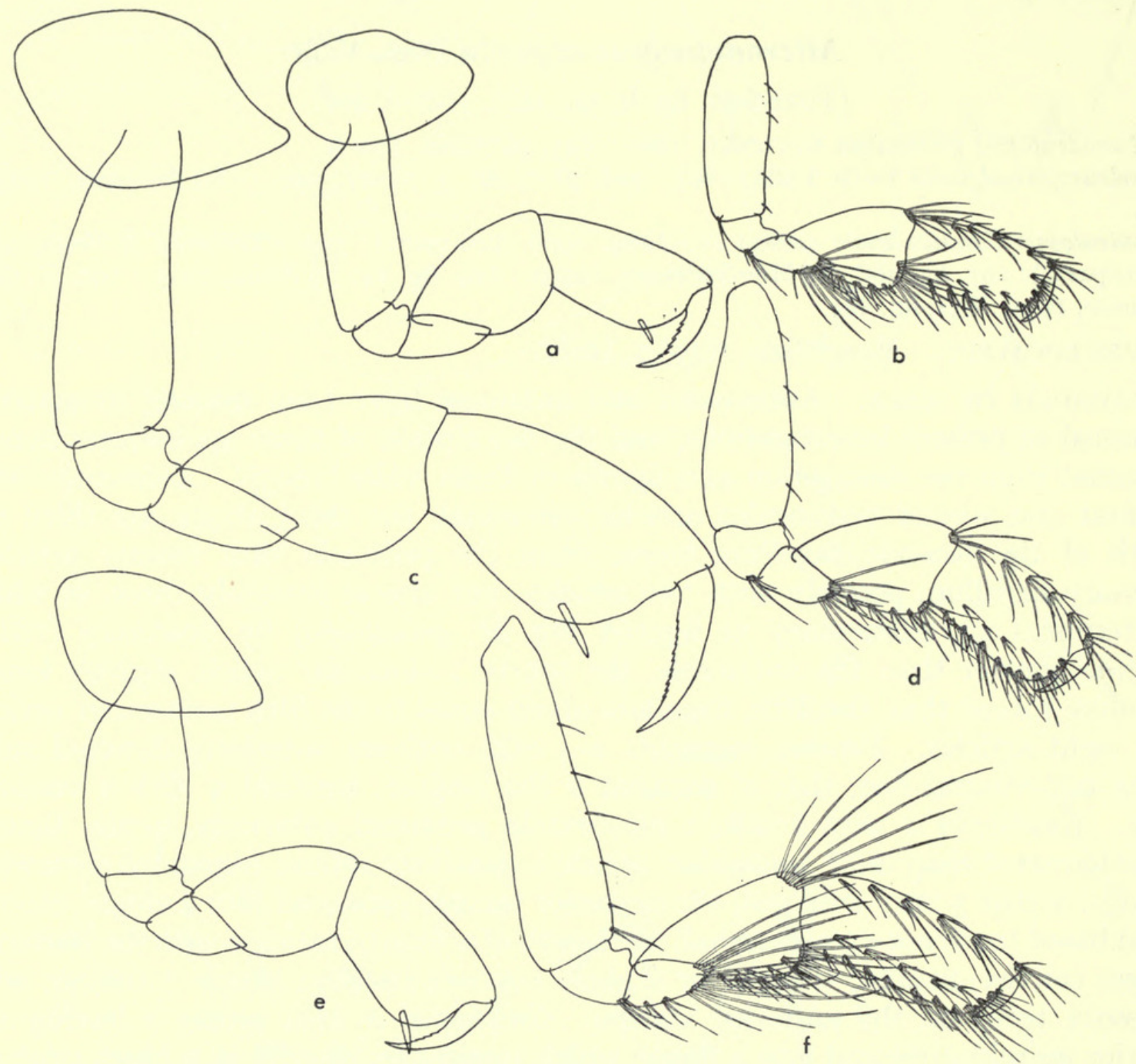

FIG. Io. Microdeutopus damnoniensis (Bate). (a) Female gnathopod I, Plymouth, Devon.

(b) Female gnathopod 2, Plymouth, Devon. Microdeutopus anomalus (Rathke). (c) Female gnathopod I, Plymouth, Devon. (f) Female gnathopod 2, Plymouth, Devon. Microdeutopus algicola Della Valle. (d) Female gnathopod 2, Naples, Italy. (e) Female gnathopod I, Naples, Italy.

or $M$. damnoniensis, and it is noteworthy that a male $M$. algicola was discovered during present re-examinations of $M$. stationis material in the Chevreux collections. Male $M$. algicola are distinguishable from those of $M$. damnoniensis, in having the tooth on article 5 of gnathopod I (Text-figs. $8 \mathrm{~g}-\mathrm{h}$ ) broad-based and triangular, whereas in $M$. damnoniensis (Text-fig. 8f) it is slender throughout its length, arising 
at the posterior distal angle only. The present species also differs from $M$. damnoniensis in the structure of gnathopod 2 (Text-fig. 9b), which has articles 5 and 6 slender, as in $M$. anomalus and in the form of uropod 3 (Text-fig. gf), which has slender elongate rami. In lacking an accessory tooth on article 5 of the male gnathopod $\mathrm{I}$, $M$. algicola differs from typical $M$. anomalus which usually possesses such a tooth. In specimens of the latter species lacking an accessory tooth (including immature specimens) the primary tooth is structurally very different, being longer and more slender, with the posterior margin more smoothly rounded, and with a narrower base, than it is in $M$. algicola. In addition, the flange on the anterior margin of article 2 of gnathopod 2 terminates distally in a more markedly developed process in $M$. algicola than in $M$. anomalus.

Ecology. At Mergellina (Della Valle, I893) among attached algae on the shore,

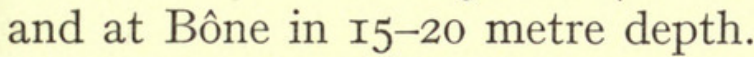

Distribution. Difficult to ascertain, due to the scarcity of reliable records. The present author has seen material from Naples, Italy and Bône, Algeria, and considers that the $M$. grillotalpa Sowinsky from Sevastopol in the Black Sea, refers to this species. The species may prove to be widely distributed in the Mediterranean region, and Black Sea.

\section{THE " SCHMITTI " GROUP OF SPECIES}

The "Schmitti" group of species occurs over a wide geographical area, around both the Pacific and Atlantic coasts of the Americas. So far material has been examined from a number of isolated geographical localities, and regional morphological differences are difficult to assign to varietal, subspecific and specific status. Nevertheless there seems at present to be justification for grouping these forms into at least three species, of which $M$. schmitti Shoemaker and $M$. hancocki Myers are sympatric, overlapping in their distribution and maintaining their separate identities. It is clear that ecological studies on the "schmitti" group of species would be of considerable value.

Males of the "schmitti" group, with the exception of $M$. schmitti itself, differ from those of all other species of Microdeutopus by the development of a tooth on the anterior margin of article 5 of gnathopod I. M. schmitti differs from $M . g r y l$ lotalpa Costa (the only species with which it could be confused) by having article 2 of gnathopod 2 concave and smooth on the anterior margin, whereas in M. gryllotalpa the anterior margin is convex and crenated. Females of $M$. schmitti differ from those of all other known species in the genus (but see also Hansenella longicornis Chevreux, p. I38) by the development of a tooth or teeth on the posterior margin of article 5 of gnathopod I. Females of other species in the "schmitti" group are without recognizable diagnostic features and their identification in the absence of males cannot be attempted with certainty. Most apparent differences in structure between $M$. schmitti and the smaller species $M$. hancocki and $M$. trichopus are due to neoteny. The rami of the third uropod of mature female $M$. hancocki and $M$. trichopus, for example, correspond to those of immature specimens of $M$. schmitti of a similar size. 


\section{Microdeutopus schmitti Shoemaker}

(Text-figs. II, I3b, d, I4a-c, f, g, 1, I5, I6a-b, d, 20m, pl. Ib)

Microdeutopus schmitti Shoemaker, I942 : I8, fig. 6; Barnard, 1958:29; Barnard, 1959:32, pl. 9; Myers, I968b : in press.

Type locality. Bahia de Magdalena, Baja California, Mexico.

Diagnosis of Male. Paragnaths with the mandibular processes relatively short and stout. Antennule slightly over one third the body length, the first and second peduncular articles subequal, the third a little less than one half the length of the

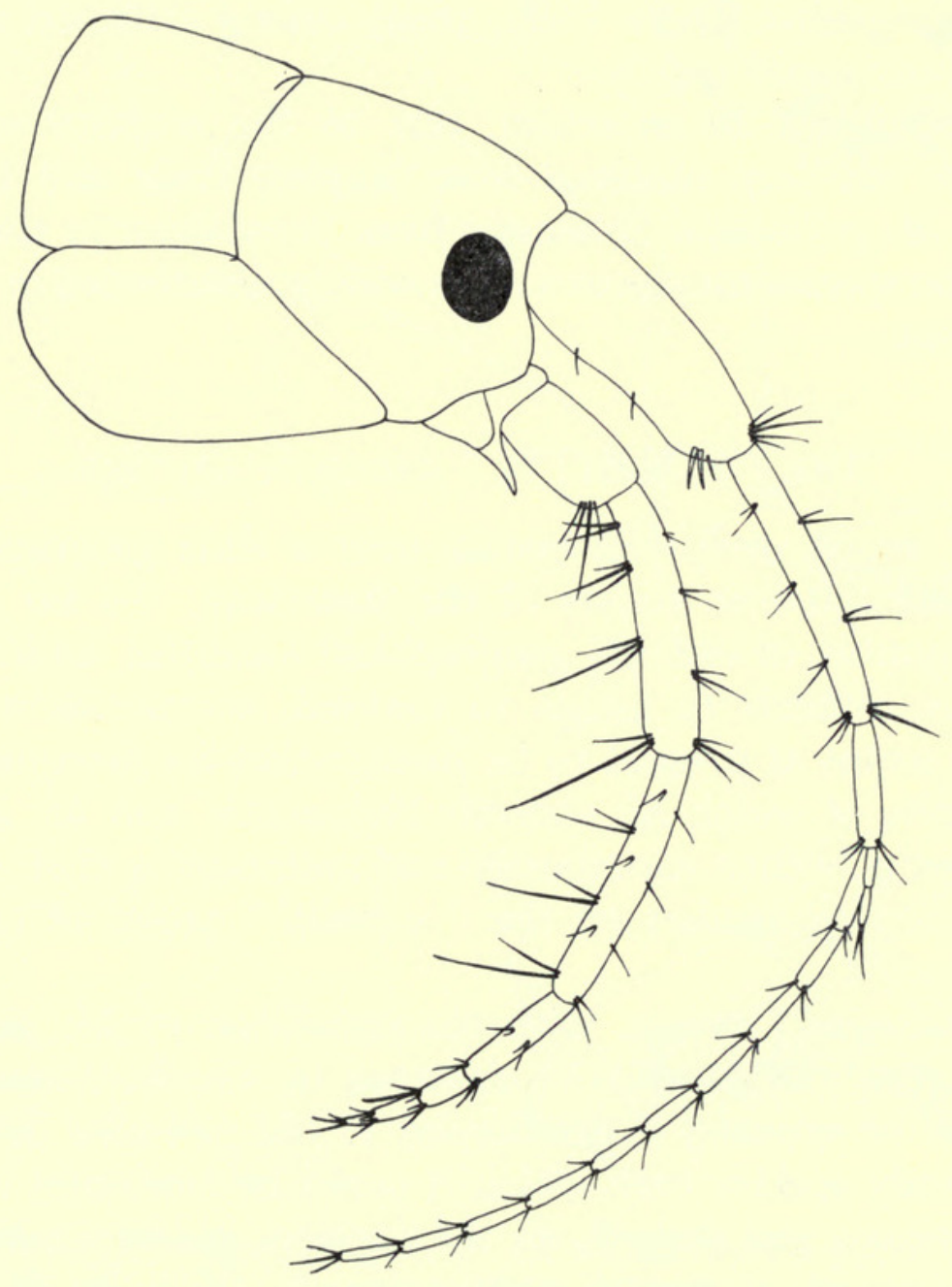

FIg. II. Microdeutopus schmitti Shoemaker. Male head, Bahia de Salinas, Costa Rica.

second; flagellum about equal in length to the peduncle, normally with up to ten articles (maximum recorded twelve); accessory flagellum with three articles, the third article rudimentary. Antenna about two thirds the length of the antennule, the fourth and fifth peduncular articles subequal; flagellum shorter than the fifth peduncular article, with four articles, of which the first is equal to the combined length of the terminal three. Peraeon segments 3-6 each with a short, robust, 


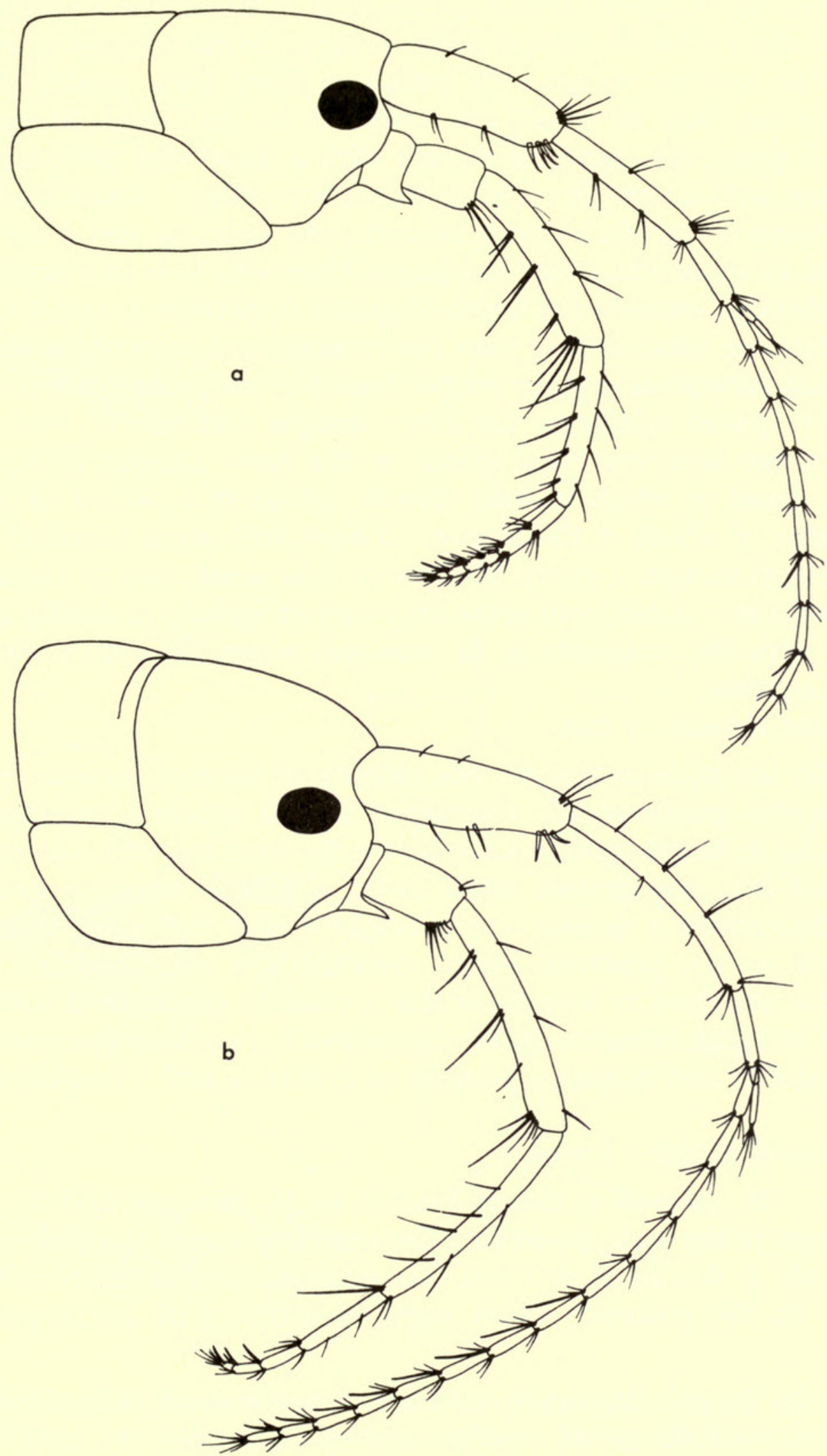

Fig. I2. Microdeutopus hancocki Myers. (a) Male head, Bahia de Salinas, Costa Rica (Paratype). Microdeutopus trichopus Myers. (b) Male head, Isabela Island, Galapagos (Paratype). 
anteriorly directed spine in the mid-ventral line. Gnathopod I with article I moderately produced anteriorly, rounded; article 2 expanded, oval, article 4 roughly triangular, with relatively short setae on the posterior margin; article 5 longer than broad, without teeth on the anterior margin, the posterior distal angle produced into a large, stout tooth, at the base of which are from one to four small forward projecting teeth; article 6 short, the posterior margin with a distal and proximal lobe; article 7 relatively long, with accessory teeth on its posterior edge. Gnathopod 2 with article 2 somewhat concave on its anterior margin, the anterior distal corner produced into a rounded lobe; article 5 slightly longer than article 6 and expanded distally, where it considerably exceeds the width of article 6 ; articles 4 , and 5 with numerous long, finely pectinate setae arising from the anterior and posterior margins. Uropod 3 with the rami subequal, slightly longer than the peduncle; endopodite with two to four equally spaced spines on the inner margin and one or two on the outer; exopodite with two well separated spines on the inner margin, and on the outer a solitary spine, basal to which in fully mature adults is a pair of closely associated spines, the outer of which is the longer. Telson with each terminal crest bearing on its distal dorsal margin a group of three or four setae, two or three of which are short and spiniform. Additional setae may appear spiniform during growth, which is in contrast with the condition in $M$. stationis where the spines are always quite distinct from the setae.

Maximum size of male : $5 \mathrm{~mm}$.

Female. As the male except for the absence of ventral peraeon spines, and the sexually dimorphic gnathopoda. Gnathopod I with article 2 unexpanded; articles 5 and 6 subequal in length, article 5 distinctly the broader, with the posterior distal angle produced into one or two small teeth, article 6 with the anterior margins roughly parallel; article 7 slender, considerably longer than the palmar region with accessory teeth on the posterior edge. Gnathopod 2 with article 2 unexpanded; articles 5 and 6 subequal in length, article 5 roughly pentagonal with the anterior margin almost straight, broadening distally, where it considerably exceeds the breadth of article 6 ; anterior and posterior margins of articles 4 and 5 bearing long pectinate setae.

Maximum size of female : $6 \mathrm{~mm}$.

Discussion. M. schmitti is closely related to $M$. hancocki and $M$. trichopus but differs from these in the male, by having the anterior margin of article 5 of gnathopod I (Text-figs. I3b, d) devoid of any toothlike processes and in the female by the presence of teeth on the posterior distal angle of article 5 of gnathopod I (Text-fig. I6b, d).

Ecology. In the sub-littoral to a recorded depth of 42 metres (off Point Loma Light, California). Tolerant of a wide range of conditions, on mud, fine or course sand, and rock substrata, among various vegetation, shells, and coral.

Distribution (Text-fig. I5). Along the coasts of California (Cayucos, Point Conception, Point Loma, San Clemente, and Newport), Baja California (El Coyote, Bahia de San Quintin, Bahia de Magdalena and Cape San Lucas) and Costa Rica (South Viradores Islands, Playa Blanca and Bahia de Salinas). 




Fig. I3. Microdeutopus hancocki Myers. (a) Male gnathopod I, Bahia de Salinas, Costa Rica (Holotype). (c) Male gnathopod I, Salango Island, Equador. Microdeutopus schmitti Shoemaker. (b) Male gnathopod I, Bahia de San Quintin, Baja California.

(d) Male gnathopod I, Bahia de Salinas, Costa Rica. Microdeutopus trichopus Myers.

(e) Male gnathopod I, Isabela Island, Galapagos (Holotype). Microdeutopus sp. nov.?

(f) Male gnathopod I, Tortugas, Florida, U.S.A. (g) Male gnathopod I, Tortugas, Florida, U.S.A. 


\section{Microdeutopus hancocki Myers}

(Text-figs. I2a, I3a, c, I4d, h, m, I5, I6c, e, 2ok, pl. Ia)

Microdeutopus hancocki Myers, I968b : In press.

Type locality. Bahia de Salinas, Costa Rica.

Diagnosis of male. Antenmules and antennae not noticably different from those of $M$. schmitti. Paragnaths with the mandibular processes longer and more slender than in $M$. schmitti. Peraeon segments 3-5 each with a short robust, anteriorly directed spine in the mid-ventral line, segment 6 with a small or vestigial spine. Gnathopod I with article I moderately produced anteriorly, rounded; article 2 markedly expanded anteroproximally; article 4 roughly triangular, with very long setae on the posterior margin; article 5 longer than broad, oval, with a median dentiform process on the anterior margin, and at the posterior distal angle, three stout teeth, the most distal of which is the longest; article 6 short, with a single lobe on the posterior margin; article 7 relatively long, with accessory teeth on the posterior edge. Gnathopod 2 with article 2 concave on the anterior margin; article 5 considerably longer than article 6 but scarcely broader; articles 4 and 5 with numerous long, finely pectinate setae arising from the anterior and posterior margins. Uropod 3 and telson scarcely differing from those of $M$. schmitti of a comparable size.

Maximum size of male $3.8 \mathrm{~mm}$.

Female. As the male except for the absence of ventral peraeon spines, and the sexually dimorphic gnathopoda. Gnathopod I similar to that of $M$. schmitti but with the posterior margin of article 5 without teeth at the posterior distal angle. Gnathopod 2 scarcely differing from that of $M$. schmitti, but with the pentagonal shape of article 5 less well marked.

Maximum size of female $4 \cdot \mathrm{I} \mathrm{mm}$.

Discussion. $M$. hancocki is very closely related to $M$. schmitti, from which it differs in the male having a tooth-like process on the anterior margin of article 5 of gnathopod I (Text-fig. I3a, c), and article 4 of this appendage bearing very long setae. In addition the structure of the ventral peraeon spines (Text-fig. 2ok) and paragnath (Pl. Ia) and the shape of the second gnathopod (Text-fig. I4m) distinguishes the present species from $M$. schmitti. It differs from $M$. trichopus by having article 6 of gnathopod I devoid of any forward projecting teeth on its posterior margin.

Ecology. Apparently more habitat-specific than $M$. schmitti, having been recorded at present only from sandy bottoms to a depth of about I8 metres.

Distribution (Text-fig. I5). Costa Rica (Bahia de Salinas), Panama (Bahia Honda), Equador (Salango Island), and Galapagos (Isabela Island).

crest of male telson, Bahia de Salinas, Costa Rica (Paratype). (m) Male gnathopod 2, Bahia de Salinas, Costa Rica (Paratype). Microdeutopus trichopus Myers.(e) Male uropod 3, Isabela Island, Galapagos (Holotype). (i) Dorsal view of left terminal crest of male telson, Isabela Island, Galapagos (Holotype). (j) Male gnathopod 2, Isabela Island, Galapagos (Paratype). Microdeutopus sp. nov.? (k) Male gnathopod 2, Tortugas, Florida. 

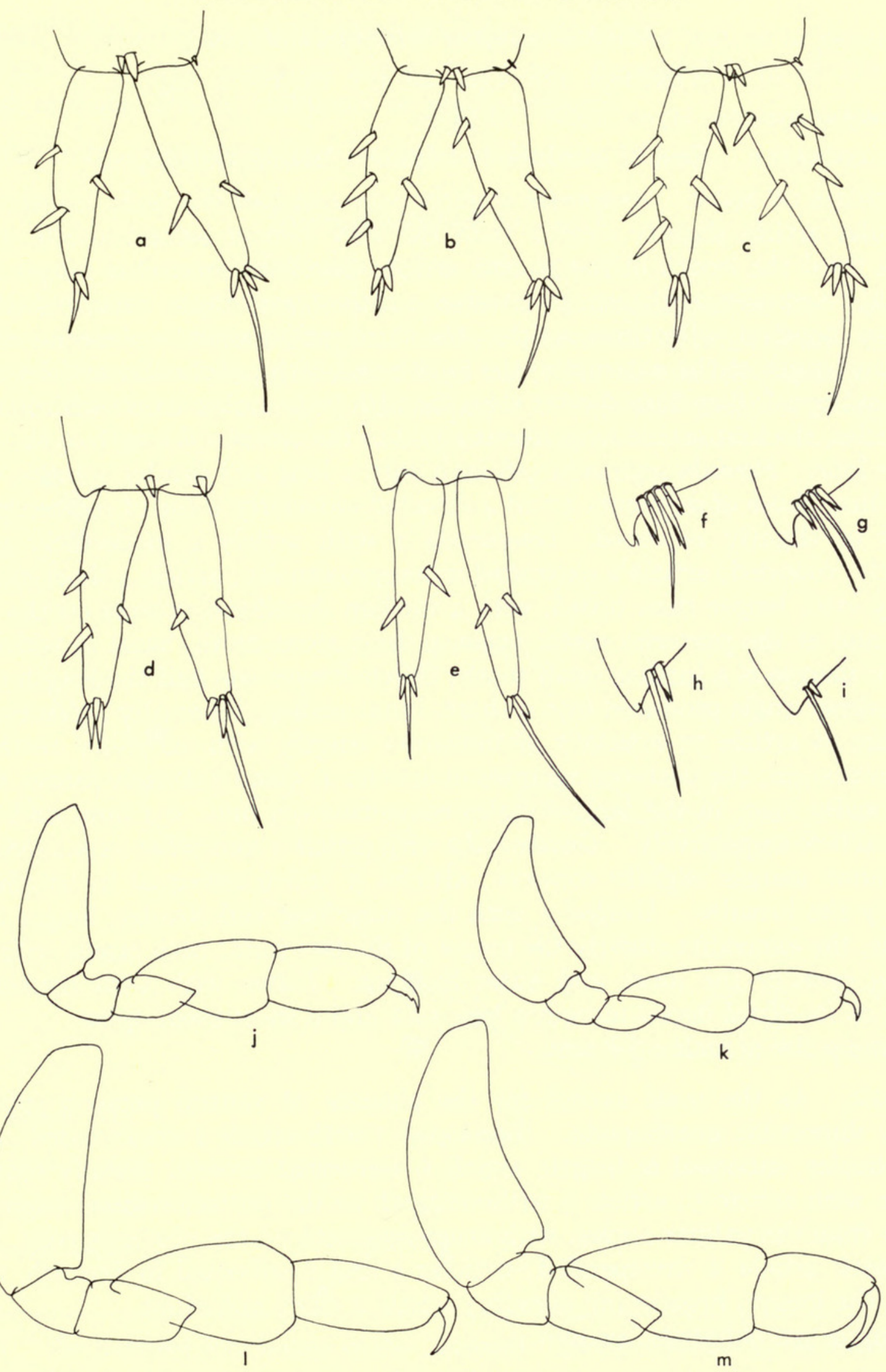

FIG. I4. Microdeutopus schmitti Shoemaker. (a)-(c) Male uropod 3, all figured the same size (and therefore each at a different scale) for easy comparison. (a) $3.0 \mathrm{~mm}$. $\hat{\sigma}$ (b) $4.5 \mathrm{~mm}$ ô (c) $5.0 \mathrm{~mm}$. $\widehat{\sigma}$, Bahia de San Quintin, Baja California. (f) (g) Dorsal view of left terminal crest of male telson, Bahia de San Quintin, Baja California. (l) Male gnathopod 2, Bahia de San Quintin, Baja California. Microdeutopus hancocki Myers. (d) Male uropod 3, Bahia de Salinas, Costa Rica (Holotype). (h) Dorsal view of left terminal 


\section{Microdeutopus trichopus Myers}

(Text-figs. I2b, I3e, I4e, i, j, I5, I6f-g, 20g)

Microdeutopus trichopus Myers, I968b : In press.

Type locality. East of south end of Isabela Island, Galapagos.

Diagnosis of male. Antennule slightly over one half the body length, the first peduncular article slightly shorter than the very slender second article, the third about a third the length of the second article; flagellum somewhat longer than the peduncle, normally with up to twelve articles (maximum recorded thirteen); accessory flagellum with three articles, the third rudimentary. Antenna about two thirds the length of the antennule, the fourth and fifth peduncular articles elongate, slender subequal; flagellum shorter than the fifth peduncular article with four, rarely five articles, the first article long, about equal to the combined length of the terminal three or four. Peraeon segments 3-6 each with a long and slender spine in the midventral line, those of segments 3 and 4 directed anteriorly those of segments 5 and 6 straight or slightly recurved. Gnathopod I with article I moderately produced anteriorly, rounded; article 2 expanded anteroproximally; article 4 short and bulky; article 5 oval, longer than broad, with a median dentiform process on the anterior margin and at the posterior distal angle, a short stout tooth, basal to which on the posterior margin is a further small tooth; article 6 over one half the length of article 5 , the palmar angle produced into a short, blunt ending, forwardly projecting tooth, opposable to article 7; article 7 of moderate length, with accessory teeth on the posterior margin; the posterior margins of articles 4,5 and 6 densely setose, the setae exceptionally long, in the largest males measuring $0.5 \mathrm{~mm} ., 0.4 \mathrm{~mm}$. and $0.3 \mathrm{~mm}$. on each article respectively. Gnathopod 2 with article 2 somewhat expanded distally, the anterior margin slightly concave; articles 5 and 6 subequal in length, article 5 slightly the broader. Uropod 3 with the rami long and slender, longer than the peduncle, the exopodite slightly the longer of the two rami; each ramus with a single spine on each of the inner and outer margins. Telson with each terminal crest bearing on its distal dorsal margin a long seta and a short stout spine.

Maximum size of male : $3.8 \mathrm{~mm}$.

Female. As the male except for the absence of ventral peraeon spines, and sexually dimorphic gnathopoda. Gnathopod I with article 2 unexpanded, articles 5 and 6 slender, subequal in length, article 6 somewhat broader distally than at the junction with article 5 ; article 5 without teeth at the posterior distal angle; article 7 longer than the palmar region, with accessory teeth on the posterior edge. Gnathopod 2 with article 2 unexpanded; articles 5 and 6 subequal in breadth, article 6 slightly the longer, broadening distally; article 7 short and stout.

Maximum size of female: $4.0 \mathrm{~mm}$.

Discussion. M. trichopus differs in the male from all other known Microdeutopus species (but see following form and Lembopsis Pearse, (p. I39), in having the posterior margin of article 6 of gnathopod I (Text-fig. I3c) produced into a forward projecting tooth opposable to article 7 .

Ecology. M. trichopus appears to be a relatively deep water species having 
been absent from samples of $M$. hancocki taken in shallow waters in geographical areas where the present species is known to occur. Recorded from 58 -rio metres over mud, and also among nullipores on sandy bottoms.

Distribution. Galapagos (two localities off Isabella Island).

\section{Microdeutopus sp. nov.?}

(Text-figs. I3f-g. I4k, I5, 20)

Two males and a single female of a species of Microdeutopus of the "schmitti" group, were examined, from Tortugas, Florida. This material most closely resembles $M$. trichopus from the Galapagos archipelago but it differs from that species particularly in the structure of the male gnathopod I. This has article 4 elongate and



FIG. I5. The recorded distribution of the "schmitti" group of species in the Americas.

rectangular in the present material, whereas it is short and triangular in $M$. trichopus, in addition article 6 is short and article 7 opposable to the teeth of both articles 5 and 6 in present material, whereas in $M$. trichopus article 6 is over half the length of the article 5, with article 7 opposable to the teeth of article 6 only. Lastly, the setation of gnathopod I is considerably more sparse in present material than in $M$. trichopus. On gnathopod 2 article 5 is slightly longer than article 6 in present material, whilst the same two articles are subequal in $M$. trichopus. 



FIG. I6. Microdeutopus schmitti Shoemaker. (a) Female gnathopod 2, Bahia de San Quintin, Baja California. (b) Female gnathopod I, Bahia de San Quintin, Baja California. (d) Female gnathopod I, Bahia de Salinas, Costa Rica. Microdeutopus hancocki Myers. (c) Female gnathopod 2, Bahia Honda, Panama (Paratype). (e) Female gnathopod I, Bahia Honda, Panama (Paratype). Microdeutopus trichopus Myers. (f) Female gnathopod 2, Isabela Island, Galapagos (Paratype). (g) Female gnathopod I, Isabela Island, Galapagos (Paratype). 
The present form is separated geographically from $M$. trichopus by the Central American isthmus, which has not been severed since the late Miocene, so one might expect the two forms to be specifically distinct. This possibility is strengthened by what is known so far of the ecology of the two forms, M. trichopus occurring in, and apparently restricted to, muddy and sandy bottoms in over 50 metres depth, while present material is found in relatively shallow waters amongst weeds.

More abundant material from a wider range of localities is required before the true taxonomic status of the present form can be elucidated.

Description of male. Antennules and antennae missing. Peraeon segments 3-6 each with a spine on the mid-ventral line, those of segments 3 and 4 directed anteriorly, those of segments 5 and 6 straight or slightly recurved. Gnathopod I with article I moderately produced anteriorly, rounded; article 2 markedly expanded anteroproximally; article 4 very elongate, roughly rectangular; article 5 oval, longer than broad, with a median dentiform process on the anterior margin, and at the posterior distal angle, a short stout tooth, basal to which, on the posterior margin, are two further small teeth; article 6 about one third the length of article 5, the palmar angle produced into a short, blunt ending, irregular, forward projecting tooth, basal to which is a small lateral projection; article 7 relatively long, opposable to the teeth of both articles 5 and 6 ; the posterior margins of articles 4,5 , and 6 bearing long setae. Gnathopod 2 with article 2 very slender basally, markedly expanded proximally; article 5 somewhat longer and broader than article 6. Uropod 3 with the rami long and slender, longer than the peduncle, the exopodite the longer of the two rami, each ramus with a single spine on its inner margin. Telson with each terminal crest bearing on its distal dorsal margin, a long seta, and a short spine.

Length of males : $3.4 \mathrm{~mm}$. and $3.5 \mathrm{~mm}$.

Female. Antennules missing. Antennae about one third the body length, the fourth and fifth peduncular articles elongate, slender, subequal; flagellum shorter than the fifth peduncular article, with four articles, the first article long, slightly shorter than the combined length of the terminal three. Gnathopods I and 2 not differing from those of $M$. trichopus.

Length of female : $3 \cdot 3 \mathrm{~mm}$.

Material. I $\hat{o}$ and I $q$; station 48-30, 9th August, I930, east and south of Loggerhead Light, Dry Tortugas, Monroe Co., Florida, in 20-20 metres. I $0^{\text {; }}$; station I2-3I, 26th June, I93I, Tortugas, Florida $\left(24^{\circ} 36^{\prime} \mathrm{N} .82^{\circ} 56^{\prime} \mathrm{W}\right.$. approx. from chart) in I8-20 metres (low water) net tow-weedy haul.

\section{Microdeutopus armatus Chevreux}

(Text-figs. I7d, I8, 20l)

Microdeutopus armatus Chevreux, I886:XLI; Chevreux, I887b:312, pl. 5, figs. II-I2; Chevreux, I887a : 92; Stebbing, I906:589; Chevreux \& Fage, I925: 296, figs. 303, 307; Barnard, $1958: 29$.

Stimpsonella armata (Chevreux) Della Valle, I $893: 422$, pl. 4, fig. 8, pl. I I figs. I3-24; Chevreux, I900: 89 ; Norman I905a : 25 . 
Type locality. North East of Basse-Kikerie, France.

Diagnosis of male. Antennule between one half and two thirds the body length, the second peduncular article longer than the first, the third a little over one third the length of the second; flagellum longer than the peduncle, normally with up to fourteen articles (maximum recorded sixteen); accessory flagellum with two articles,


FIG. I7. Microdeutopus chelifer (Bate). (a) Male head, with (b) a transverse section and (c) a lateral view of the third peduncular article of the antenna, Jersey, Channel Islands. Microdeutopus armatus Chevreaux. (d) Male head, Villefranche, France. 
the second article rudimentary. Antenna about two thirds the length of the antennule, the fourth and fifth peduncular articles subequal; flagellum slightly shorter than the fifth peduncular article with five articles. Peraeon segments $2-5$ each with a spine in the mid-ventral line, that of segment 2 slender hook-shaped, directed anteriorly, those of segments 3-5 robust anteriorly directed, that of segment 5 the shortest. Gnathopod I with article I moderately produced anteriorly, acute; article 2 short and greatly expanded; article 5 almost as broad as long, the posterior distal angle produced into a large, broad, blunt ended tooth; article 6 short, the posterior margin irregularly lobed; article 7 relatively long. Gnathopod 2 with article 2 expanded, the anterior margin produced into a crenated flange; articles 5 and 6 roughly rectangular, subequal in length and breadth, article 6 with the palmar angle produced into a short tooth. Uropod 3 with the rami subequal, slightly shorter than the peduncle; endopodite with a pair of spines on the inner dorsal margin near the apex, and one long and one short terminal seta, exopodite with a similar pair of terminal setae. Telson with each terminal crest bearing, on its distal dorsal margin, a long seta.

Maximum size of male : $3 \mathrm{~mm}$.

Female. As the male except for the structure of the sexually dimorphic gnathopoda, and absence of ventral peraeon spines. Gnathopod I with article 2 somewhat dilated; article 6 longer than article 5, with the anterior and posterior margins roughly parallel, article 7 very elongate, exceeding in length the palmar region. Gnathopod 2 with article 2 expanded, the antero-distal corner produced into a lobe; article 6 considerably longer than article 5, with the palmar angle produced into a broadbased triangular process.

Maximum size of female : $4 \mathrm{~mm}$.

Discussion. $M$. armatus differs in the male from all other species in the genus, except $M$. chelifer, in having the second gnathopod chelate. It differs from the latter species by having the fifth and sixth articles of gnathopod 2 (Text-fig. I8d), subequal in length and breadth, whereas in M. chelifer (Text-fig. I9c), article 6 is much shorter and much broader than article 5. There is no justification for placing these two species together in a distinct genus (Stimpsonella Della Valle) as suggested by Della Valle (1893) on the basis of the chelate male second gnathopoda, since in other respects they exhibit no greater affinity with each other than they do with other Microdeutopus species. The most generally useful character enabling the identification of females of $M$. armatus is the structure of the second gnathopod (Text-fig. I8e), which has a pronounced projection at the antero-distal corner of article 2, and a triangular process at the palmar angle of article 6 . In addition article 2 of the first gnathopod (Text-fig. I8a) is somewhat dilated.

Ecology. On soft grey mud (type locality), fine or coarse sands, in the sublittoral, in Io-9o metres. At Naples (Della Valle, I893), associated with Urothoe and Ampelisca.

Distribution. France, from the type locality, southwards along the coasts of the Bay of Biscay (Le Croisic, Gulf of Gascony), Portugal, and in the Mediterranean off the coasts of France (Antibes, Villefranche) Corsica (Bonifacio) and Italy (Naples). 


\section{Microdeutopus chelifer (Bate)}

(Text-figs. I7a-c, I9, 20n)

Stimpsonia chelifera Bate, I862 : 162, pl. 29, fig. 9; Bate \& Westwood, 1863: 285; Stebbing, I $878: 34$, pl. 5, figs. $2-3$; Norman, I $886:$ I 7 .

Microdeutopus chelifer (Bate) Stebbing, I888:334; Stebbing, I906:589; Chevreux \& Fage, I925 : 295, fig. 306; Barnard, I958: 29.

[Non] Microdeutopus chelifer Haswell, I879: 340, pl. 22, fig. 3.

Stimpsonella chelifera (Bate) Della Valle, I893:424, pl. 56, figs. 42-45; Norman, I905a : 25; Norman, $1905 \mathrm{~b}: 82$; Norman \& Scott, I906 : 84; Norman, $1907: 368$.

TyPe Locality. Salcombe, Devon, England.

Diagnosis of male. Antennule slightly over one half the body length, the second peduncular article a little longer than the first, the third over one third the length of the second; flagellum longer than the peduncle, normally with up to fifteen articles (maximum recorded seventeen); accessory flagellum with three articles, the third

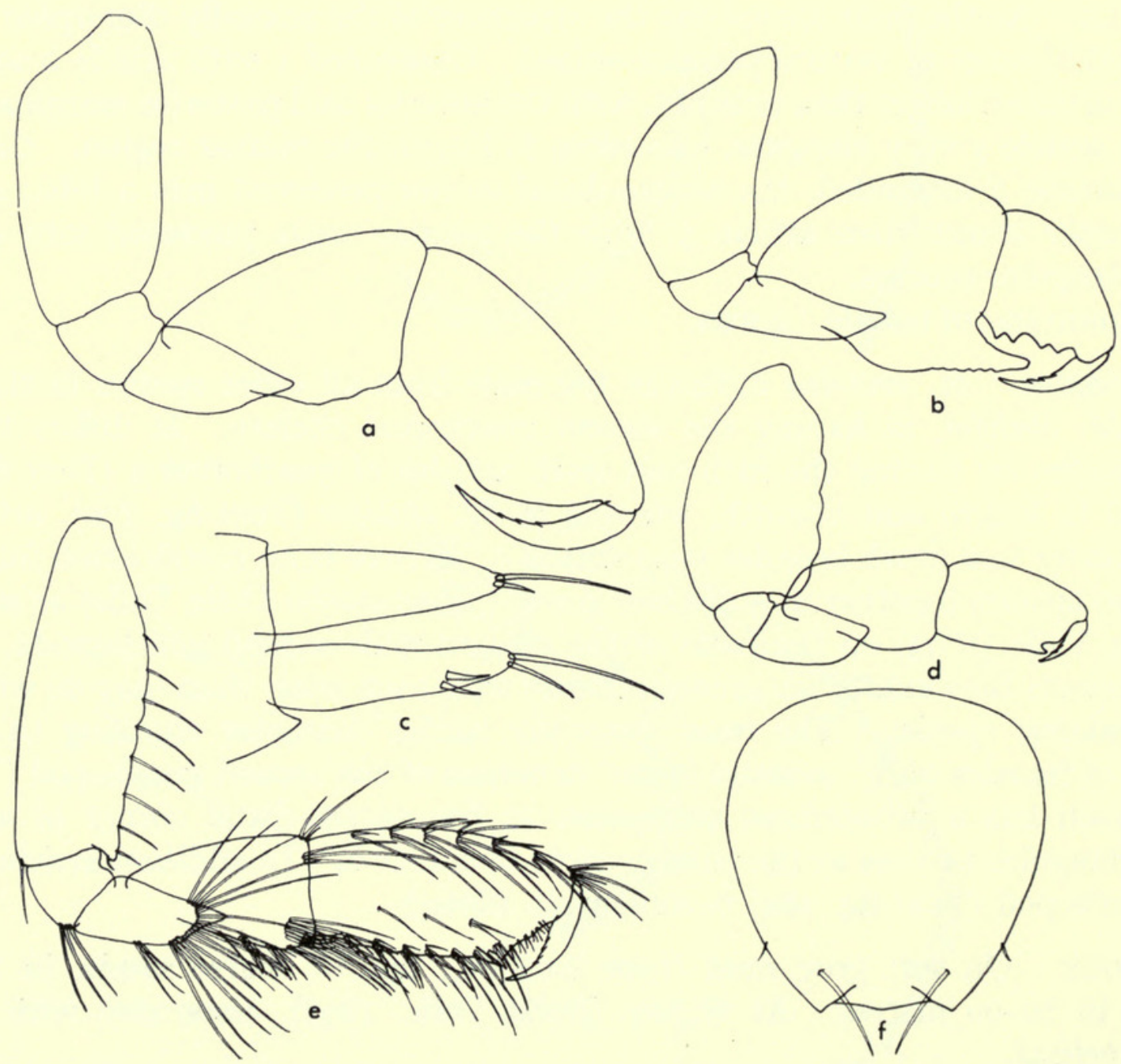

FIG. I8. Microdeutopus armatus Chevreux. (a) Female gnathopod I, Le Croisic, France.

(b) Male gnathopod I, Le Croisic, France. (c) Male uropod 3, Le Croisic, France. (d)

Male gnathopod 2, Le Croisic, France. (e) Female gnathopod 2, Le Croisic, France.

(f) Male telson, Le Croisic, France. 
article rudimentary. Antenna longer than the antennule, the third peduncular article with its lower outer margin produced into a flattened lobe, the fourth peduncular article very slightly shorter than the fifth; flagellum longer than the fifth peduncular article, normally with up to ten articles (maximum recorded eleven).
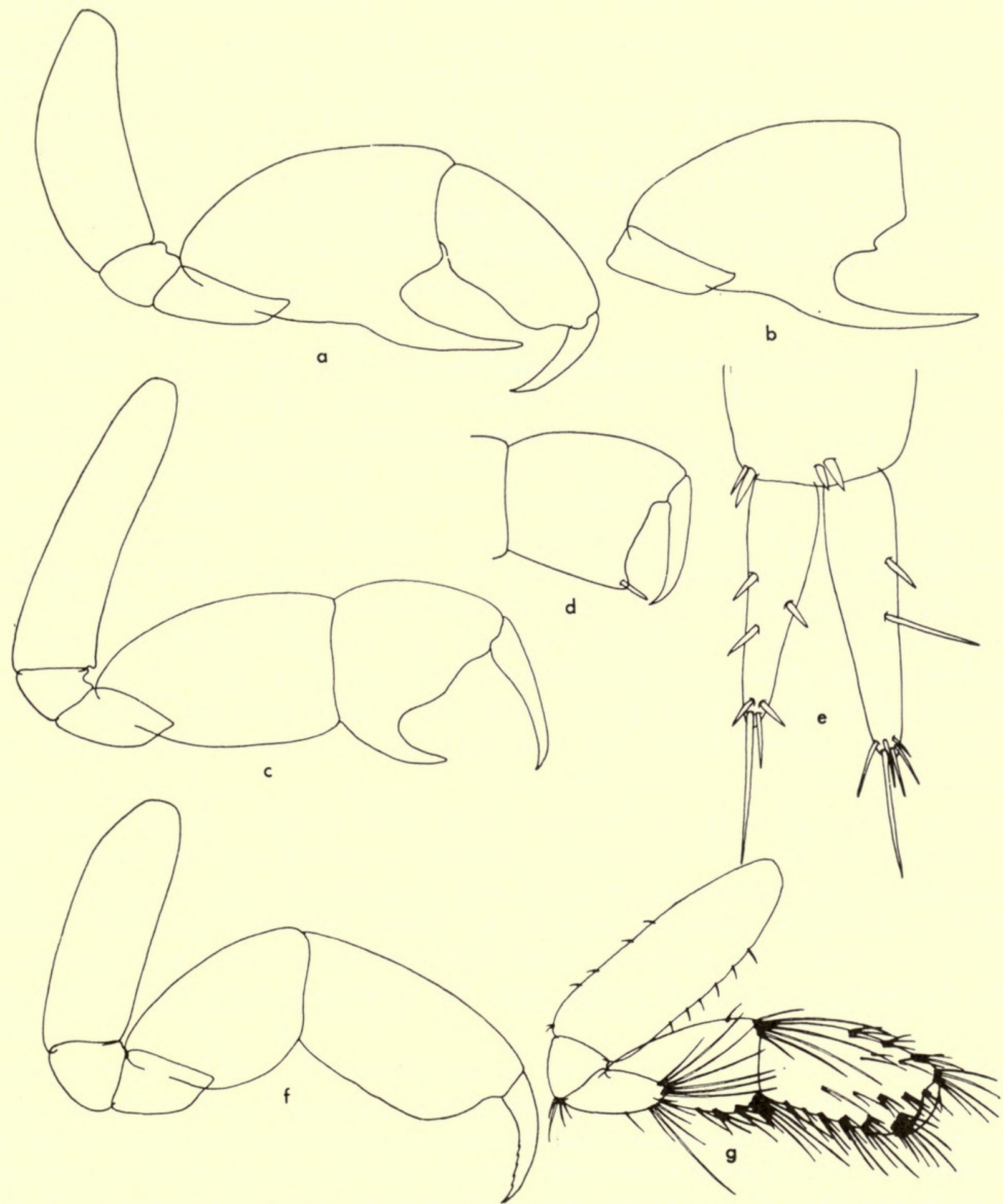

FIG. I9. Microdeutopus chelifer (Bate). (a) Male gnathopod I, Paignton, Devon, England.

(b) Male gnathopod I, articles 4 and 5, Khios, Greece. (c) Male gnathopod 2, Paignton, Devon, England. (d) Male (Immature) gnathopod 2, articles 6 and 7, Khios, Greece. (e) Male uropod 3, Brittany, France. (f) Female gnathopod I, Guernsey, Channel Islands. (g) Female gnathopod 2, Guernsey, Channel Islands. 
Peraeon segments 2-4 each with an anteriorly directed process in the mid-ventral line, those of segments 2 and 3 long, slender, spiniform, that of segment 4 short, robust. Gnathopod I with article I strongly produced anteriorly, very acute; article 2 scarcely expanded; article 5 very enlarged, but longer than broad, the posterior margin produced sub-distally into a long, narrow, inward curving tooth, distal to which in some, but not all specimens, is a further small tooth; article 6 relatively long, the posterior margin undulate; article 7 robust. Gnathopod 2 with article 2 narrow and elongate, with a small projection at the antero-distal corner; article 6 shorter and broader than article 5 , with the palmar region produced into a process, which in young males is short and broad, bearing a stout spine at its tip, but in mature males is drawn out into a long inward curving tooth, when the spine is usually obsolete; article 7 very long, opposable to the palmar process. Uropod 3 with the rami elongate and slender, subequal in length with the peduncle;

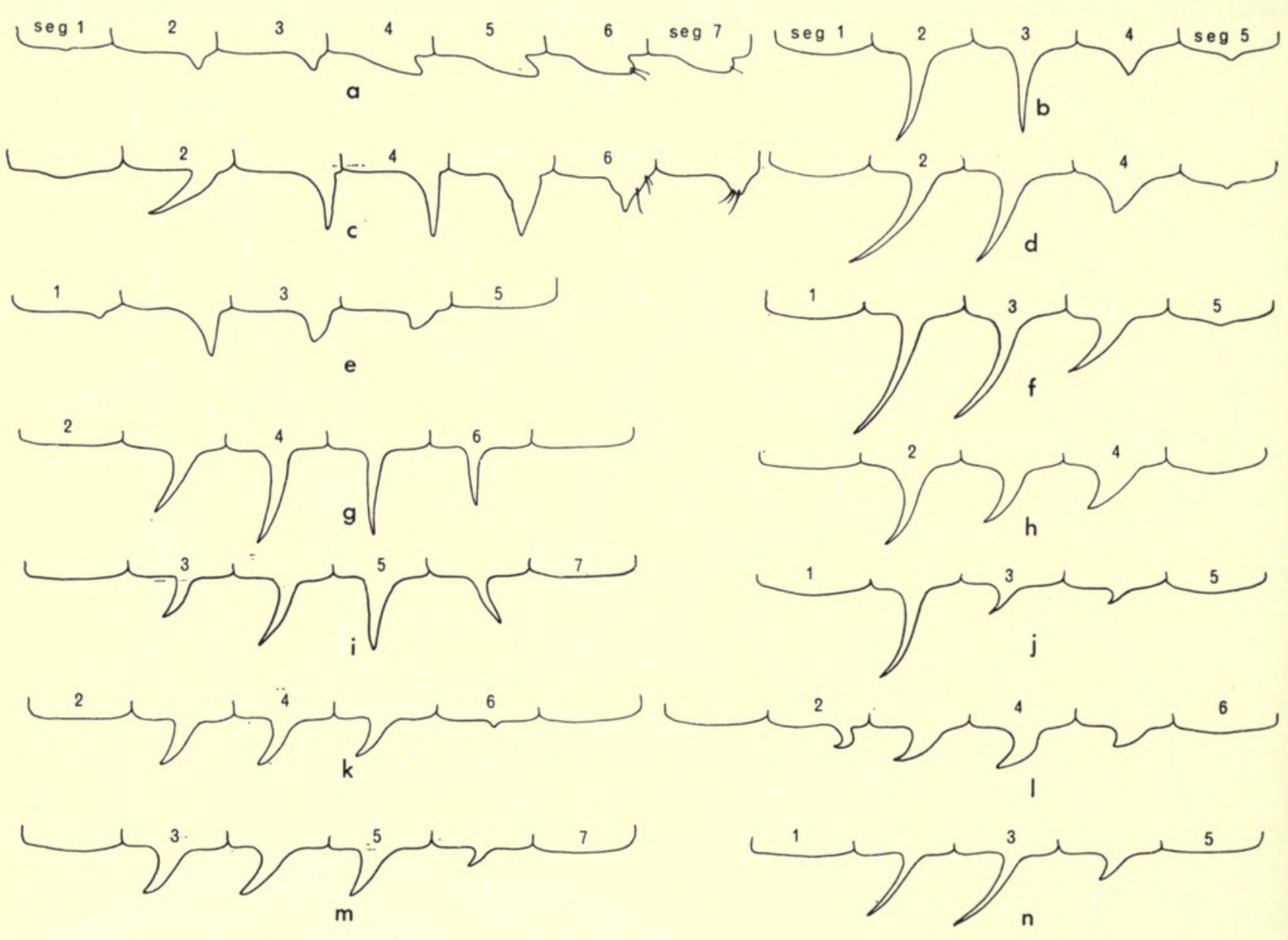

FIG. 20. Ventral peraeon processes in Microdeutopus species. (a) M. gryllotalpa Costa Isefjord, Denmark. (b) $M$. anomalus (Rathke) Falmouth, Cornwall, England. (c) $M$. versiculatus (Bate) Falmouth, Cornwall, England. (d) M. anomalus (Rathke) Plymouth, Devon, England. (e) $M$. stationis Della Valle Guernsey, Channel Islands. (f) $M$. algicola Della Valle Bône, Algeria. (g) $M$. trichopus Myers Isabela Island, Galapagos. (h) M. damnoniensis (Bate) Bandol, France. (i) M. sp. nov. ? Tortugas, Florida, U.S.A. (j) M. damnoniensis (Bate) Plymouth, Devon, England. (k) M. hancocki Myers Bahia de Salinas, Costa Rica. (l) M. armatus Chevreux Villefranche, France. (m) M. schmitti Shoemaker Bahia de Salinas, Costa Rica. (n) M. chelifer (Bate) Jersey, Channel Islands. 
exopodite slightly the longer of the two rami, with two isolated spines on the outer margin, of which the more distal is particularly long; endopodite with two well separated spines on the inner margin and one on the outer; each ramus with a terminal cluster of spines, of which one is greatly elongated. Telson with each terminal crest bearing on its distal dorsal margin, a group of up to 3 setae.

Maximum size of male : $8 \mathrm{~mm}$.

Female. As the male except for the absence of ventral peraeon spines and the sexually dimorphic antennae and gnathopoda. Antenna with the third peduncular article unmodified, and the entire appendage less well developed than that of the male, such that it does not exceed the length of the antennule. Gnathopod I with article 2 moderately expanded; article 6 longer than article 5, about twice as long as broad, with the anterior and posterior margins roughly parallel; article 7 robust, equal in length to the palmar region. Gnathopod 2 similar to gnathopod I but more slender, the palmar region more transverse.

Maximum size of female : $8 \mathrm{~mm}$.

Discussion. As in the preceding species, the second gnathopoda of the male are chelate. In the present species, however, article 6 of this appendage (Text-fig. I9c) is much shorter and broader than article 5, whereas in $M$. armatus (Text-fig. I8d) the fifth and sixth articles are more or less subequal in length and breadth. $M$. chelifer is unique among the known Microdeutopus species in having sexually dimorphic antennae, but this feature is not considered to be a sufficient reason for separating the present species from the genus Microdeutopus (see also Stebbing, I888). Females have few diagnostic characters, but important identification features when taken in combination are: the accessory flagellum of the antennule having three articles (Text-fig. I7a), the third uropod rami having their sparse spination of solitary spines, the more distal of two spines on the outer margin of the exopodite being exceptionally long (Text-fig. I9c) and the telson bearing setae, but no spines.

Ecology. In the scarcely tidal Mediterranean the present species occurs in shallow waters, among Cystoseira, Chondrus, Saccorhiza etc. On the Atlantic and English Channel coasts, the species is also found in the shallow sub-littoral among Laminaria holdfasts and other weeds, but it most frequently inhabits the littoral zone, among algae in rock pools often high up on the shore, particularly in sheltered places with a high accumulation of silt, often where there is some brackish water influence.

Distribution. Along the south-western coasts of the British Isles (Studland, Torbay, Wembury Bay, Salcombe, Portwrinkle), the Channel Islands and the adjoining French coast, and thence at a number of localities along the coasts of the Bay of Biscay to Guethery in the extreme south. Recorded from Cadiz, and probably occurs in a number of favourable localities around the coasts of Spain and Portugal. In the Mediterranean it has been recorded from the coast of France (Sète, Monaco, Antibes, Villefranche) and in the Aegean from the Greek Island of Khios, off the Turkish coast. The ?Stimpsonia sp. of Sowinsky (I898) from the Black sea may refer to this species. 
Microdeutopus sporadhi sp. nov.

(Text-figs. 2I, 22)

DESCRIPTION OF MALE HOLOTYPE. Mouthparts not differing significantly from those of other members of the genus. Head lateral-lobes moderately well developed, obtuse; eye reniform. Antennule about two thirds the body length, the first peduncular article shorter than the second, the third less than one half the length of the

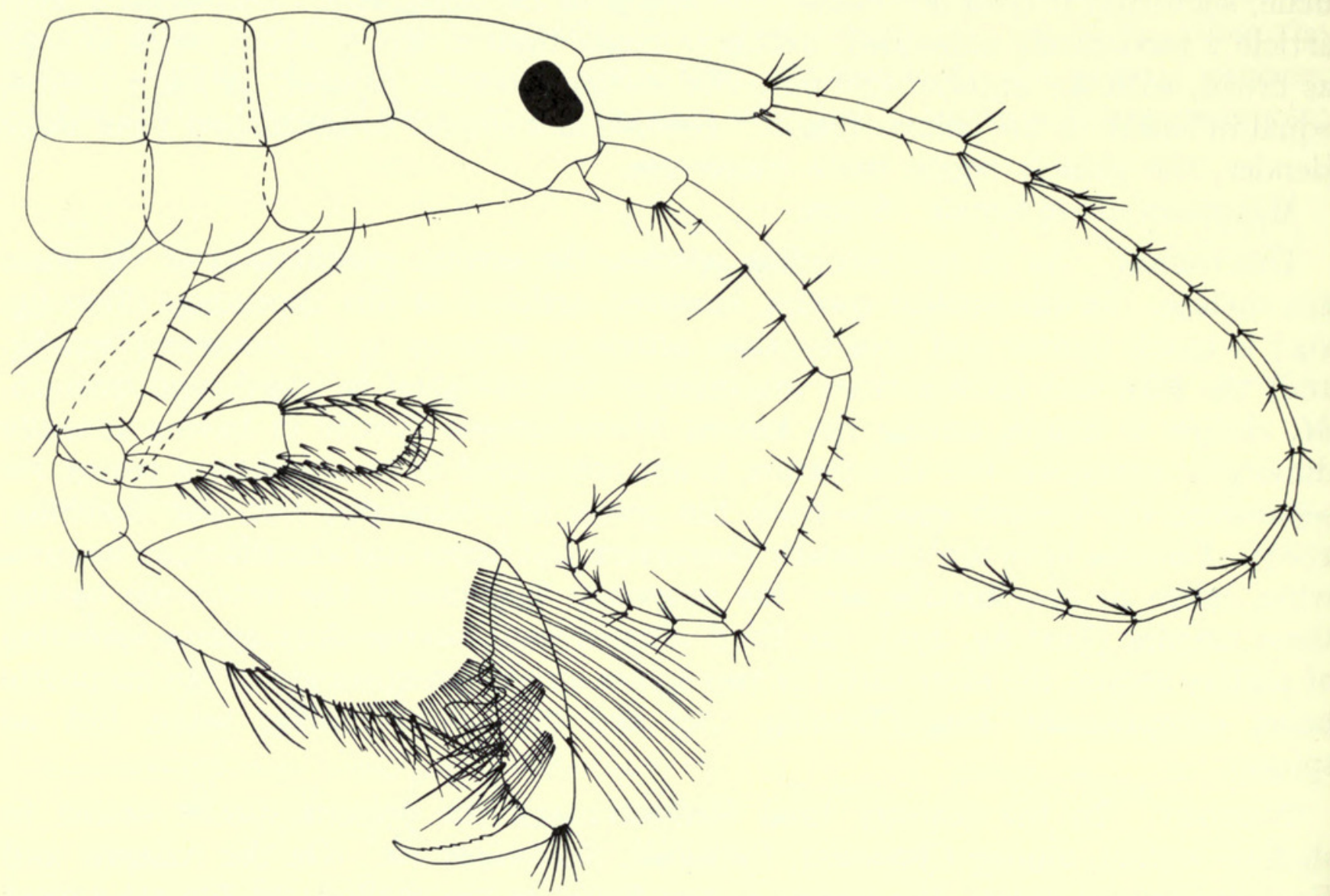

FIG. 2I. Microdeutopus sporadhi sp. nov. Anterior end of male holotype, Emborios Bay, Khios, Greece.

second; flagellum about one and one half the length of the peduncle, with thirteen articles; accessory flagellum with two articles, the second article minute, shorter than the first article of the primary flagellum. Antenna shorter than the antennule, the fourth and fifth peduncular articles subequal; flagellum scarcely longer than the fifth peduncular article, with seven articles. Peraeon segments 2 and 3 each with a robust, anteriorly directed spine in the mid-ventral line, that of segment 2 the longer. Gnathopod I with article I strongly produced anteriorly, somewhat attenuated, article 2 elongate, relatively slender, but broadening distally, its anterior margin excavate for the reception of the carpus when folded, article 4 slender, scarcely over lapping the posterior margin of article 5 , article 5 grossly expanded, longer than broad, 
slender basally, broad distally, with groups of long fine setae arising from within the distal and postero-distal margins, and with the posterior distal angle produced into two distinct teeth, the proximal (outer) tooth curved inward, relatively long and slender, terminating acutely, the distal (inner) short, robust, obtuse, article 6 elongate and slender, broadening somewhat distally, but with the palmar region almost obsolete, the posterior margin almost straight, article 7 very long, though slightly shorter than article 6, with accessory teeth on the posterior margin. Gnathopod 2 with article 2 relatively short and broad, the anterior margin almost straight, articles 5 and 6 subequal in length and breadth, article 7 relatively short. Peraeopods 3-7 of the typical Microdeutopus structure. Uropod 3 with the rami short, not exceeding the length of the peduncle, exopodite slightly the longer of the two rami, devoid of spines on the lateral margins, terminating distally in a group of five long setae, of which the two most distal arise from a vestigial second article; endopodite with a single median spine on the inner margin and a group of four

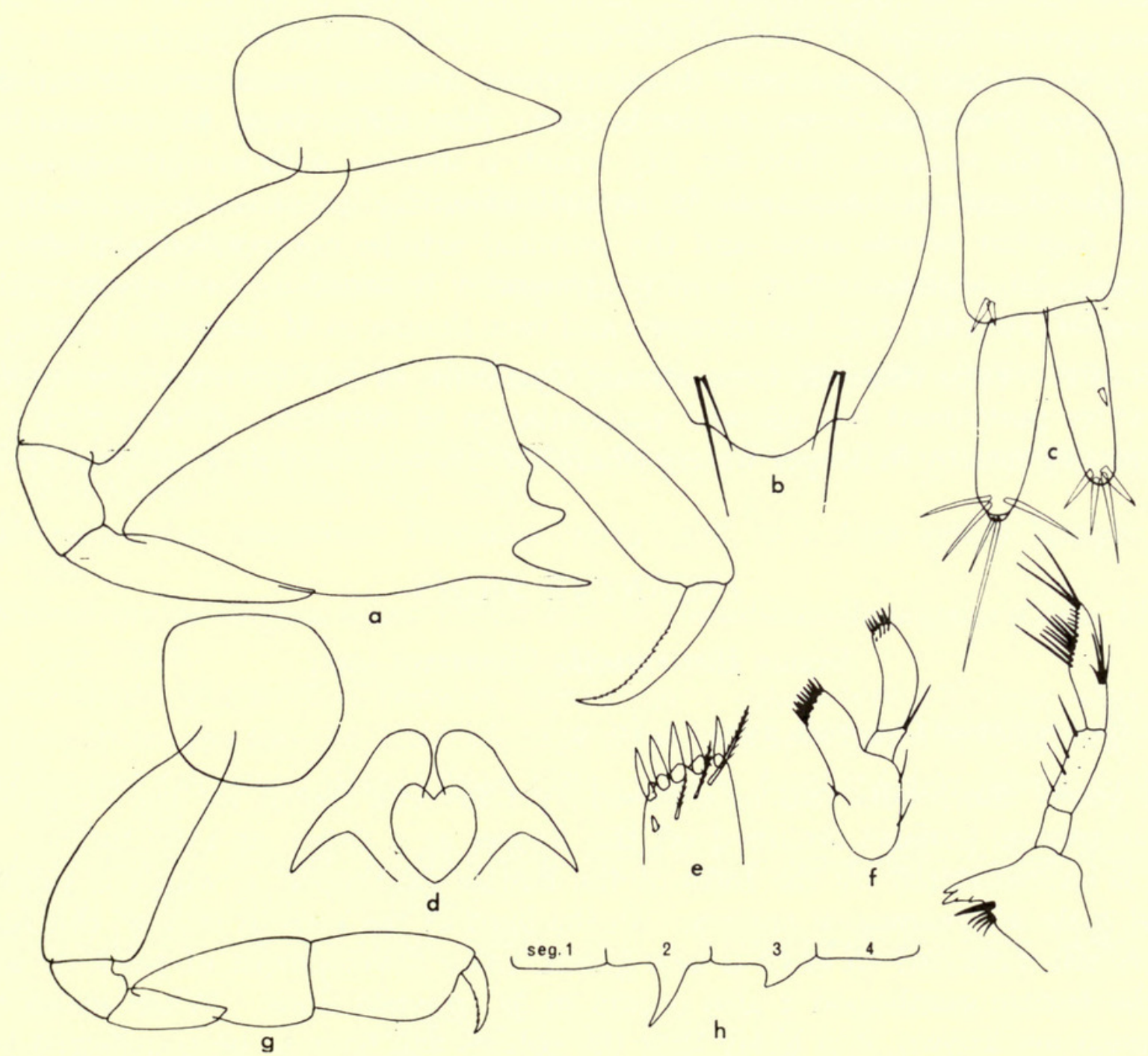

FIG. 22. Microdeutopus sporadhi sp. nov. Male paratypes. (a) Gnathopod I. (b) Telson.

(c) Uropod 3. (d) Paragnath. (e) Terminal article of maxillule palp. (f) Maxillule.

(g) Gnathopod 2. (h) Ventral peraeon processes. (i) Mandible. 
terminal setae. Telson of the usual Microdeutopus form, each terminal crest bearing on its distal dorsal margin a pair of long setae of unequal length.

Length : $3.0 \mathrm{~mm}$.

Male paratypes. Agree closely with the holotype in all diagnostic characters. Antennal flagellum of one paratype with 8 articles, otherwise this appendage also invariable.

Length of paratypes $2 \cdot 8-3 \cdot 2 \mathrm{~mm}$.

Female. Unknown.

Types. §o Holotype B.M. (N.H.) Registration Number I968.I.8. I

I o Paratype B.M.(N.H.) Registration Number I968.r. 8.2

2 ơ Paratypes U.S.N.M. Catalogue number I22544.

Type locality. Emborios Bay, Khios, Greece.

Material. 6 o from the type locality, August 8-Irth, I967.

Discussion. M. sporadhi does not show close affinity with any of the previously described species of Microdentopus. Males differ from those of all other Microdeutopus species except $M$. haswelli Stebbing in the structure of gnathopod I (Textfig. 22a), which has the posterior distal angle of article 5 produced into two teeth, of which the proximal (outer) is the longer. They differ from $M$. haswelli in the structure of the antenna (Text-fig. $2 \mathrm{I}$ ), which is slender, with a relatively elongate and slender flagellum, whereas in $M$. haswelli (Text-fig. 4b) it is sub-pediform, with the first flagellar article stout and the terminal articles compressed and obscurely articulate. In addition article 2 of gnathopod 2 is broad and relatively short in $M$. sporadhi (Text-fig. 22g), but elongate and very slender in $M$. haswelli (Text-fig. $3 \mathrm{~h}$ ).

Ecology. Type material from among Cystoseira in 0-2 metres where relatively little water movement has allowed accumulation of detritus. Absent from Cystoseira growing nearby in deeper waters where there is relatively little detritus accumulation.

\section{INCERTAE SEDIS}

\section{Genus Hansenella Chevreux I909}

Hansenella longicornis Chevreux, I909: 5, fig. 3 .

The genus Hansenella was established by Chevreux (I909) for the reception of three ovigerous females obtained off the Azores at a depth of 1360 metres. The genus is characterized by the form of the female gnathopod I, which is similar to that of male Microdeutopus species. In the light of the present review, this feature alone is not sufficient to erect a new genus, since development of teeth on article 5 of the female gnathopod I also occurs in $M$. schmitti Shoe. When males of $H$. longicornis are known, it is likely that the species will have to be transferred to the genus Microdeutopus, but it should be emphasized that the female gnathopod I is far more massively developed in $H$. longicornis than in any known Microdeutopus female. 


\section{SPECIES DUBIA}

\section{Microdeutopus tittii Heller}

Microdeutopus tittii Heller, I866 : 48, pl. 4, fig. 8.

It is doubtful if this form described from a single specimen collected at Pirano in the Adriatic is a distinct species. Della Valle (I893) considered it to be a much mutilated specimen of $M$. gryllotalpa Costa, but even allowing for mutilation, the undilated article 2 of gnathopod 2 would appear to precluds that species The relative lengths of the antennules and antennae could apply to $M$. chelifer (Bate), but the non-cheliferous gnathopod 2 precludes that species. Allowing for the mutilation of the antennules and antennae, which is of frequent occurrence in the delicate Aoridae, this species is most likely to be $M$. anomalus (Rathke) as suggested by Stebbing (I906) or M. stationis Della Valle. The long slender antenna with a flagellum of eleven articles would most favour the latter species.

\section{Species not attributable to Microdeutopus Costa}

I. Microdentopus anomalus Bate, I862 : I64. = + Aora typica Kroyer, I845: 328.

2. Microdeutopus arcticus Hansen, I887 : 23I. = Lembos arcticus (Hansen) Stebbing, I895: 207.

3. Microdeuteropus australis Haswell, I879:27I = Lemboides australis (Haswell) Stebbing, I899: 350 .

4. Microdenteropus bidentatus Stebbing, $1876: 73 .=$ Lembos websterii Bate, I856: 58 .

5. Microdeutopus kraemmeri Reid, I95I : 25I. = Lembopsis kraemmeri (Reid) Myers, Ig68c : In press.

6. Microdentopus longipes (Lilljeborg) Bate, $\mathrm{I} 862: \mathrm{I} 66 .=$ Lembos longipes (Lilljeborg) Stebbing, I895 : 207.

7. Microdeutopus maculatus Thomson, I879:33I. = q Aora typica Kroyer, I845 328.

8. Microdeutopus megnae Giles, I888 : 23I. = Grandidierella megnae (Giles) Chilton, I92I : 548 .

9. Microdenteropus mortoni Haswell, I879: $339=$ ๙ैAora typica Kroyer, I845 : 328.

I0. Microdeuteropus tenuipes Haswell, I879:339= o Aora typica Kroyer, I845 : 328.

II. Microdeutopus tenuis (Dana) Bate, I862 : I65. = Lembos temuis (Dana) Stebbing, I895: 207 .

I2. Microdeutopus tridens Schellenberg, I938:74=Lembopsis tridens (Schellenberg) Myers, I968c : In press.

13. Microdentopus websterii (Bate, I862) : I64. $=$ Lembos websterii Bate, I856 : 58 .

\section{ACKNOWLEDGEMENTS}

My thanks are due to Dr. E. Naylor for much helpful discussion and criticism, to N.E.R.C. for a grant with which to carry out the work, to the Khios Committee for defraying travel costs and to Professor E. W. Knight-Jones for laboratory zooL. I7, 4 . 
facilities. I am indebted to the Trustees of the British Museum (Natural History) for allowing me to study the collection, to Drs. J. L. Barnard, T. E. Bowman and R. B. Manning (United States National Museum), Dr. J. S. Garth (Hancock Foundation, University of Southern California), Dr. J. C. Yaldwyn (Australian Museum, Sydney), Dr. M. Amanieu (Station Biolgique D'Arcachon), Dr. J. Forest (Museum National D'Histoire Naturelle, Paris) and to Dr. E. Rasmussen and Dr. T. Wolff (Universitetets Zoologiske Museum, Copenhagen) for invaluable loans of material, and to the Director of the Plymouth Laboratory for facilities and access to collections.

\section{REFERENCES}

Andersson, A. I954. Notes on some gammarids of the genus Microdeutopus from the West Coast of Sweden. Ark. Zool. $6: 247-254$, figs. I-4.

BARNARD, J. L. I958. Index to the families, genera and species of the Gammaridean Amphipoda (Crustacea) Contr. Allan Hancock Fdn. 19 : I-I45.

- 1959. Estuarine Amphipoda. In Ecology of Amphipoda and polychaeta of Newport Bay, California. Contr. Allan Hancock Fdn. 21 : I-Io6, pls. I-I4.

I96ra. Relationship of Californian amphipod faunas in Newport Bay and in the open sea. Pac. Natural, 2(4) : I66-186, figs. I-2.

— I96rb. Gammaridean Amphipoda from depths of 400-60oo metres. Galathea Rep. $5: 23-$ I 28 , figs. I-83.

- I962. Benthic marine Amphipoda of Southern California, Families Aoridae, Photidae, Ischyroceridae, Corophiidae, Podoceridae. Pac. Natural. 3(I) : I-72, figs. I-32.

- I964. Revision of some Families, Genera and Species of Gammaridean Amphipoda. Crustaceana, 7 : 49-74.

Bate, S. I856. On the Edriophthalmous Crustacea I : Amphipoda. Rep. Bv. Ass. Advmt Sci. I855: I8-62, pls. I2-22.

— 1857. A synopsis of the British Edriophthalmous Crustacea Part I : Amphipoda. Ann. Mag. Nat. Hist. s. 2, 19 (I IO) : I 35-I52.

- r862. Catalogue of the specimens of amphipodous Crustacea in the collection of the British Museum: 399 pp., 58 pls., London.

Bate, S. \& Westwood, J. O. I863. A history of the British sessile-eyed Crustacea. London, I : $507 \mathrm{pp}$.

BJöRCK, A. I9I5. Biologisk-faunistiska undersökningar av Öresund 2. Crustacea Malacostraca och Pantopoda. Acta Univ. lund. N.F., 11(7) : I-98.

Blanc, H. I884. Die amphipoden der Kieler Bucht. Nova Acta Akad. Caesar. Leop. Carol. 47(2) : 37-104, pls. 6-10.

Blegvad, H. I922. On the biology of some Danish gammarids and mysids. Rep. Dan. biol. Stn. 28 : I-IO3, figs. I-I I.

Boеcк, A. I87o. Crustacea Amphipoda borealia et arctica. Forh. Vidensk Selsk. Krist. : $\mathrm{I}-200$.

I876. De Sandinaviske og Arktiske amphipoder. 2: I6I-713, Christiana.

Brian, A. I938. Le cenobiosi dei pali nella laguna Veneta. Atti Soc. Sci. Genova 3(2) : I2II42, figs. I-7, pl. I.

— I939. Gli amfipodi della Laguna di Venezia. Boll. Musei Lab. Zool. Anat. comp. R. Univ. Genova, s.2, I9(IIо) : I-8, figs. I-2.

Brown, W. L. I965. Numerical taxonomy, convergence and evolutionary reduction. Syst. Zool. 14(2) : IoI-I09, figs. I-I8.

Bruzelius, R. I859. Bidrag till Kännedomen om Skandinaviens Amphipoda Gammaridea K. Svenska Vetensk. Akad. Handl. (N.F.), 3 : I-IO4, pls. I-4.

Carausu, S. \& Carausu, A. I942. Amphipodes provenant des dragages effectués dans les eaux Roumaines de la Mer Noire. Annls. scient. Univ. Jassy, 28(2) : 66-83, figs. I-8. 
Carus, J. V. I885. Prodromus faunae mediterranea sive descriptio animalium maris mediterranei incolarum quam comparata silva rerum quatenus innotuit adjectis locis et nominibus vulgaribus eorumque auctoribus in commodum Zoologorum congessit Julius Victor Carus. 1(2) Amphipoda : 386-428, Stuttgart.

Catta, J. D. I875. Note pour servir à l'histoire des amphipodes du golfe de Marseille. Revue Sci. nat. Montpellier 4(I) : I6I-I69.

Cecchini, C. \& Parenzan, P. I934. Anfipodi del Golfo de Napoli, Publ. Stag. zool. Napoli, 14(2) : I 53-250, figs. I-55.

Chevreux, E. r883. Crustacés amphipodes et isopodes des environs du Croisic. C.v. Seanc. Soc. Biol. 12 : 51 7-520.

I886. Description de trois espèces nouvelles d'amphipodes du sud-ouest de la Bretagne. Bull.Soc.Zool.Fr. 11 : XL-XLII

I887a. Sur les crustacés amphipodes de la côte ouest de Bretagne. C.r. hebd. Seanc. Acad.Sci.Paris. 104 : 90-93.

I 887 b. Catalogue des crustacés amphipodes marins du sud-ouest de la Bretagne, suivi d'un aperçu de la distribution géographique des amphipodes sur les côtes de France. Bull. Soc. zool. Fr. 12 : 287-340, pl. 5.

I888. Sur quelques crustacés amphipodes recueillis aux environs de Cherchell. C.r. Ass. fr. Avanc. Sci. 17 (2) : 343-353, pl. 6.

I90o. Amphipodes provenant des campagnes de l'Hirondelle. Résult. Camp. scient. Prince Albert I, 16 : I-I95, pls. I-I8.

I9or. Amphipodes recueillis par la “Melita " sur les côtes occidentale et méridionale de Corse. C.r. Ass. fr. Avanc. Sci. 30 (2) : 692-699, pl. 5.

1909. Diagnose d'amphipodes nouveaux provenant des campagnes de la Princess-Alice dans l'Atlantique Nord. Bull. Inst. océanogr. Monaco, 150 : I-7, figs. I-3.

r9ro. Campagne de la "Melita”. Les amphipodes d’Algérie et de Tunisie : I. Gammarina. Mém. Soc. zool. Fr. 23 (2) : 145-285, pls. 6-2o.

I925. Amphipodes. Voyage de la Goélette Melita aux Canaries et au Sénégal i889-189o. I. Gammariens. Bull. Soc. Zool. Fr. 50 : 278-3I I, 365-398, figs. I-35.

Chevreux, E. \& Bouvier, E. L. I893. Les amphipodes de Saint-Vaast-la-Hougue. Annls. Sci. nat. s.7, 15 (2-3) : 109-144, pl. 2.

Chevreux, E. \& Fage, L. I925. Amphipodes. Faune Fr. 9 : I-488, figs. I-438.

Chickoff; G. I9I2. Contribution à l'étude de la faune de la Mer Noire; animaux récoltés sur les côtes Bulgares. Archs. Zool. exp. gen. 10 (2) : 29-39.

Chilton, C. I921. Fauna of the Chilka Lake. Amphipoda. Mem. Ind. Mus. 5 : 52 I-558, figs. I-I 2 .

Costa, A. I853. Relazione sulla memoria del Dottor Achille Costa, dia Richerche su Crostacei Amfipodi del Regno di Napoli. Rend. Soc. Borbon, 2 (N.S.) : r66-I78.

I857. Richerche sui crostacei anfipodi del regno di Napoli. Rend. Soc. Borbon 2 : 165235, pls. I-4.

DAhL, E. I946. Notes on some Amphipoda from the Gullmar fjord. Ark. Zool. 38A (8) : I-8, figs. $I-5$.

Della Valle, A. I893. Gammarini del Golfo di Napoli. Fauna Flova Golf. Neapel, 20 : I948 , pls. I-6I.

ENEQUist P. I949. Studies on the soft-bottom amphipods of the Skagerak. Zool. Bidr. Upps. 18 : 297-492, figs. I-67.

Giles, G. M. I888. Further notes on the Amphipoda of Indian waters. J. Asiat. Soc. Beng. 57 (2) : 220-255, pls. 6-I2.

GurJanova, E. I95I. Bokoplavy morei S.S.S.R. e sopredelnyx vod (Amphipoda: Gammaridea) Faune S.S.S.R. 41 : I-I03I, figs. I-705.

Hansen, H. J. I887. Oversigt over de paa Dijmphna-Togtet indsamlede Krebsdyr. in: Lütken, Dijmphna-Togtets zoologisk-botaniske Udbytte, I83-286, pls. 20-24.

HASWELl, W. A. I879. On some additional new genera and species of amphipodous crustaceans. Proc. Linn. Soc. N.S.W. $4:$ 319-350, pls. I8-24. 
Haswell, W. A. i882. Catalogue of the Australian stalk and sessile-eyed Crustacea. Austr. Mus. 326 pp. 4 pls. Sydney.

Heller, C. I866. Beiträge zur näheren Kenntnis der amphipoden des Adriatischen Meeres. Denkschr. Akad. Wiss. 26 (2) : I-62, pls. I-4.

Hоек, P. P. C. I889. Crustacea neerlandica. Tijdschr. ned. dierk. Vereen. s.2, 2: I70-234, pls. 7-IO.

Kinne, O. I963a. Adaptation, a primary mechanism of evolution. Mus. comp. Zool. Spec. publ.: 27-5o, figs. 3-9.

- r $1963 \mathrm{~b}$. The effects of temperature and salinity on marine and brackish-water animals. I : Temperature. Oceanogr. Mar. Biol. Ann. Rev. 1 : 30I-40.

- 1964. The effects of temperature and salinity on marine and brackish-water animals. 2: Salinity and temperature salinity combinations. Oceanogr. Mar. Biol. Ann. Rev. $2: 28 \mathrm{I}-339$.

Koenler, R. i885. La faune littorale des Iles Anglo-Normandes. Annls. Sci. nat. s.6, 20 (4) : I-62, pl. I.

Kroyer, H. I845. Carcinologiste Bidrag. Naturh. Tidsskr. s. 2, $1: 283-345$, pls. 2-3.

Kunkel B. W. I9ı. The Amphipoda of Bermuda. Trans. Conn. Acad. Arts Sci. 16 : I-r i6, figs. I-43.

LILlJEBöRG, V. I855. Öfversigt af de inom Skandinavien hittills funna arterna af slägtet Gammarus Fabr. af V. Liljeborg. K. Svenska Vetensk. Akad. Handl. I853 : 443-46o.

Lovén, P. M. I934. Zur Kenntnis einiger amphipoden und isopoden im Öresund. in: Undersökningar över Öresund. I 7. Acta Univ. lund. N.F. 30 (2) : I-I4, figs. I-4.

Meinert, F. V. A. I877. Crustacea Isopoda, Amphipoda et Decapoda Daniae: Fortegnelse over Danmarks isopode, amphipode og decapode krebsdyr. Naturh. Tidsskv. s. 3., 11 : $57-248$.

I88o. Crustacea Isopoda, Amphipoda et Decapoda Daniae: Fortegnelse over Danmarks isopode, amphipode og decapode krebsdyr. Naturh. Tidsskr. s. 3, 12: 465-5I2.

- I893. Crustacea: Malacostraca in: Det Videnskabelige udbytte af Kanonbaaden " Hauchs" Togter. I49-232, pls. I-2.

Miloslavskaia, N. I939a. Bokoplavy (Amphipoda-Gammaroidea) chernomorsko-Azovskogo basseyna. Trudy Karad. biol. st. 5 : 69-I5I, figs. I-35.

— I939b. K. ekology chernomorskeech Gammaridea v svyazee s proeeschozhdeneeem eech faoony. Trudy Karad. biol. st. 5 : I52-174.

Myers, A. A. I968a. Two Aoridae (Amphipoda: Gammaridea) including a new species of Amphideutopus Barnard from Venezuelan waters. Crustaceana 14 : 127-130.

I968b. Some Aoridae (Amphipoda: Gammaridea) collected by the Hancock expeditions to the eastern Pacific I93I-4I. Pac. Sci. "In press".

I968c. Aoridae (Amphipoda: Gammaridea) collected by the yacht " Chazalie " in tropical waters. Bull. Mus. natn. Hist. nat., Paris. In press.

- r968d. Unpublished observations.

Nebeski, O. I88o. Beiträge zur Kenntnis der amphipoden der Adria. Arb. Zool. Inst. Univ. Wien, 3 (2) : I-52, pls. I-4.

Norman, A. M. I867a. Report of the committee appointed for the purpose of exploring the coast of the Hebrides by means of the dredge. 2: On the Crustacea, Echinodermata, Polyzoa, Actinozoa and Hydrozoa. Rep. Br. Ass. Advmnt. Sci. I866: I93-2I I.

I 867 b. Reports of deep-sea dredging on the coast of Northumberland and Durham 1862-4. Crustacea. Nat. Hist. Trans. Northumb. 1 : 12-29.

- I869a. Shetland final dredging report, part 2: On the Crustacea, Tunicata, Polyzoa, Echinodermata, Actinozoa, Hydrozoa and Porifera. Rep. Br. Ass. Advmt Sci. I868: 273-288, 335-336.

I869b. in: Brady and Robertson. Notes of a week's dredging in the west of Ireland. Ann. Mag. Nat. Hist. s. 4, 3 : 353-373, pls. I8-22. 
Norman A. M. I 886. A catalogue of the Invertebrata of Europe and the Arctic and North Atlantic Oceans, which are contained in the collection of A. M. Norman. 3 : Crustacea. Mus. Norm. 47 pp.

— I905a. A catalogue of the Invertebrata of the Arctic and North Atlantic temperate ocean and Palearctic region, which are contained in the collection of the Rev. Canon A. M. Norman. 3 : Crustacea. Mus. Norm. 2nd edn. 53 pp.

r905b. Revised nomenclature of the species described in Bate and Westwood's " British sessile-eyed Crustacea" Ann. Mag. Nat. Hist. s. 7, 16:78-95.

1907. Notes on the Crustacea of the Channel Islands. Ann. Mag. Nat. Hist. s. 7, 20 (I I8): 356-37I, pls. I6-I 7 .

Norman, A. M. \& Scott, T. I906. The Crustacea of Devon and Cornwall. London : 232 pp. $24 \mathrm{pls}$.

Norman, A. M. \& Stewardson Brady, G. I909. The Crustacea of Northumberland and Durham. Trans. nat. Hist. Soc. Northumb. (N.S.), 3 (2) : 252-4I7, pls. 8-9a.

Oldevig, H. I933. Sveriges Amphipoder. Göteborgs K. Vetensk. -o. Vitterh Samh. Handl. s.B, 3 (4) : I-282, figs. I-I 24.

Pearse, A. S. I9I2. Notes on certain amphipods from the Gulf of Mexico, with descriptions of new genera and species. Proc. U.S. Natn. Mus. 43 (I936) : 369-379, figs. I-8.

Rathke, H. I843. Beiträge zur fauna Norwegens. Crustacea. Nova Acta Acad. Caesar. Leop. Carol. 20 : 63-98, pls. 3-4.

ReID, D. M. I94I. The amphipod fauna of Oldany Harbour, Sutherland. J. Anim. Ecol. 10 : 296-305.

I95I. Report on the Amphipoda (Gammaridea and Caprellidea) of the coast of tropical West Africa. Atlantide Rep. 2 : 189-29I, figs. I-58.

Salvat, B. r962. Faune des sédiments meubles intertidaux du bassin d'Arcachon. Cah. Biol. mar. 3 : 219-244.

SARS, G. O. I894. An account of the Crustacea of Norway. I, Amphipoda. London. 7II pp. 240 pls. and 8 pls.

SchellenberG, A. I934. Zur amphipoden fauna der Kieler Bucht. Schr. naturw. Ver. Schlesw.-Holst. 2 : I 29-I 44, figs. I-2.

— I938. Litorale amphipoden des tropischen Pazifiks. K. Svenska Vetensk. Akad. Handl. S.3, 16 (6) : I-IO5, figs. I-48.

- 1942. Krebstiere oder Crustacea. 4: Flohkrebse oder Amphipoda. Tievwelt Dtl. $40: 252$ pp., 204 figs.

Scotт, T. I906. A catalogue of land, freshwater, and marine Crustacea found in the basin of the river Forth and its Estuary. Proc. R. phys. Soc. Edinb. 16 : 97-I9o.

Sheard, K. I937. A catalogue of Australian Gammaridea. Trans. R. Soc. S. Austr. 61 : I729.

Shommaker, C. R. I942. Amphipod crustaceans collected on the Presidential cruise of I938. Smithson. Misc. Collns. 101 (I I) : I-52, figs. I-I 7.

Sмiтн, S. I. I874. in: Verrill, A. E., \& Smith, S. I. Report upon the invertebrate animals of Vinyard Sound and adjacent waters, with an account of the physical features of the region. Rep. U.S. Commnr. Fish. 1 : 26I-273.

SöıkA, A. G. I949. Gli anfipodi gammarini della Laguna di Venezia. Archo Oceanogr. Limnol. 6 : 165-212, figs. I-7.

Sokolowsky, A. I9oo. Die amphipoden Helgolands. Wiss. Meeresunters. Abt. Helgoland 4 : I4 I-I66, pl. 3 .

Sowinsky, W. I88o. Ob Amfipoda Sevastopolskoy boochta I. vvedene. Zap. Kiev. Obshch. Estest. $6: 87-136$, pls. 3-5.

I 895 . Vasshya rakoobrenaya (Malacostraca) sobrannaya dvoomy ooernomorskeme gloobamrname zkspedepyame 1890 e r891 godov. Zap. Kiev. Obshch. Estest. 14:225-283, pls. 4-6.

— I898. Vasshya rakoobrenaya (Malacostraca) Bosfora, po materialam sobrannim doktorom A. A. Ostroumovim v r892 e I893 gg. Zap. Kiev. Obshch. Estest. 15 (2) : 447-5I8, pls. 8-I3. 
Stebbing, T. R. R. I874. Amphipodous Crustacea. A new species and some items of Description and Nomemclature. Ann. Mag. Nat. Hist. s. 4, 14 : Io-15, pls. I-2.

I876. Description of a new species of sesile-eyed crustacean and other notices. Ann. Mag. Nat. Hist. s. 4, $17: 73-8$ o, pls. 4-5.

1878. Notes on sessile-eyed crustaceans, with description of a new species. Ann. Mag. Nat. Hist. s. 5, 1 : 3I-37, pl. 5 .

I888. Report on the Amphipoda collected by H.M.S. Challenger during the years I873-76. Rep. Challenger, 29 : I-I 737, pls. I-2 Io.

1895. Notes on Amphipoda old and new. Ann. Mag. Nat. Hist. s. 6, 16 : 205-213, pls. 8-IO.

1899. Revision of Amphipoda. Ann. Mag. Nat. Hist. s. 7, $3: 350$.

I906. Amphipoda, I. Gammaridea. Tierreich, 21 : I-806, figs. I-I27.

I9ro. Scientific results of the trawling expedition of H.M.C.S. "Thetis " off the coast of New South Wales in February and March I898. Crustacea. 5: Amphipoda. Mem. Aust. Mus. 4 (12) : 565-658, pls. 47-6o.

Stephensen, K. I927. Revideret Fortegnelse over Danmarks Arter af Amphipoda. 3. Gammaridea: Gammaridae-Podoceridae; Caprellidea. Vidensk. Meddr. dansk naturh. Foren. 84 : 107-I50.

— I929a. Amphipoda. Tierwelt N.-u. Ostsee, 14 (rof) : I88 pp., 43 figs.

- I929b. Marine Crustacea Amphipoda. Zoology Faroes 23 : I-40.

Le Suevr, R. F. I954. The Cumacea, Mysidacea, Amphipoda, Isopoda and Tanaidacea of the Channel Islands. Bull. a. Soc. jersiaise, 16 (2) : 207-2I6.

Tesch, J. J. I9I5. De amphipoden der zuidelijke Noordzee, verzameld met de "Wodan" Rapp. Verhand. Rijksinst. Vissch. -Onderz. 1 (3) : 319-374, pls. Io-I2.

- I922. Amphipoden. Flova Fauna Zuiderzee, 326-336, figs. I-7.

Thomson, G. M. I879. Additions to the amphipodous Crustacea of New Zealand. Ann. Mag. Hist. s. 5, $4:$ 329-333, pl. I6.

TRUснот, J. I963. Etude faunistique et écologique des amphipodes des faciés roucheux intertidaux de Roscoff. Cah. Biol. mar. 4 : I2I-I76, figs. I-I6.

Valcanov, A. I936. Belejki verhu nasite brachicini vodi, 2. God. sof. Univ. 32 (3) : 20934I, figs. I-3I.

Walker, A. O. I895. The Amphipoda of Bate \& Westwood's "British sessile-eyed Crustacea ". Ann. Mag. Nat. Hist. s. 6, $15: 464-476$.

— I897. Malacostraca from the west coast of Ireland. Proc. Trans. Lpool biol. Soc. 12 : I59172.

White, A. I852. A popular history of British Crustacea. $35^{8}$ pp. 20 pls. London.

\section{APPENDIX I}

Catalogue of material examined in the present work.

KEY TO ABBREVIATION OF SOURCES :
A.A.M.
Personal collections
A.M.S.
Australian Museum Sydney
B.M.N.H.
E.R.
British Museum (Natural History)
M.B.A.P.
Dr. E. Rasmussen
M.N.H.N.
Marine Biological Association, Plymouth
S.B.A.
Museum National D'Histoire Naturelle, Paris.
U.S.C.
Station Biologique D'Arcachon
U.S.N.M.
University of Southern California
U.Z.M.D.
United States National Museum (Smithsonian Institution)
Universitets Zoologiske Museum, Denmark.

* Indicates material emanating from the collections of the original author of the species. 


\section{Microdeutopus gryllotalpa Costa}

\section{England}

Chaldon Herring, Dorset U.Z.M.D.

Weymouth, Dorset B.M.N.H.

Wales

Plymouth, Devon B.M.N.H.

Swansea, Glamorgan . . A.A.M.

Denmark

"Denmark" . . . B.M.N.H.

Bohuslen . . . . U.Z.M.D.

Isefjord . . . . E.R.

France

Roskilderjord . . . E.R.

Le Croisic . . . B.M.N.H.

Arcachon . . . . S.B.A.

Spain

Valencia . . . . B.M.N.H.

Italy

Naples . . . . B.M.N.H.

Greece

Khios . . A.A.M.

U.S.A.

"N.E. America" . . B.M.N.H.

Wood's Hole, Mass. . U.S.N.M.

Marion Harbour, Mass ～. U.S.N.M.

Vinyard Sound, Mass. . . U.S.N.M.

Newport, Rhode Island U.S.N.M.

Noank, Connecticut . . U.S.N.M.

Microdeutopus versiculatus (Bate)

England

Plymouth, Devon

A.A.M.

B.M.N.H.

U.Z.M.D.

M.B.A.P.

Salcombe, Devon

B.M.N.H.

Mouth of river Yealm, Devon

B.M.N.H.

Falmouth, Cornwall . . B.M.N.H.

U.Z.M.D.

Scotland

Isle of Mull . . B.M.N.H.

Eire

Oldany Harbour, Sutherland U.Z.M.D.

Birterbuy Bay, Co. Galway . B.M.N.H.

Roundstone, Co. Galway B.M.N.H.

Westport, Co. Mayo . . B.M.N.H.

Channel Islands

Guernsey . . . . B.M.N.H.
7 ô 18 우

I 0 2 우

I ô $^{\mathrm{I}}$ 우 3 immature

500 조 500 우 1000 immature

2 수 2 우

2 oิ

43 오 56 우 I 3 immature

3 to 4 우

3 호 3 우

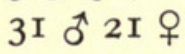

3 우

5 ธิ 9 우

I 7 ơ 26 우

I $0 \hat{0}$ I 우

20 주 37 우

2 우

72 oิ 102 ㅇ 4 immature

4 oิ 3 우 I immature

8 ơ 13 o 8 immature

Microdeutopus stationis Della Valle

Channel Islands

St. Peter's Port, Guernsey B.M.N.H. 
Corsica

Italy

Bonifacio . . . M.N.H.N.

*Naples . . . . B.M.N.H.

Algeria

Bône

Greece

Khios
M.N.H.N.

A.A.M.
I

2

I

$-$
I 우

4 추 I I 우 I immature

I ơ 2 우

3 오 I 우

I ơ HOLOTYPE

Microdeutopus haswelli Stebbing

Australia

Port Jackson . . . A.M.S.

Microdeutopus anomalus (Rathke)

England
Plymouth, Devon
A.A.M.
Falmouth, Cornwall
B.M.N.H.
U.Z.M.D.

Scotland

Eire

$\begin{array}{lllll}\text { Argyll } & \text {. } & \text {. } & \text {. } & \text { B.M.N.H. } \\ \text { Isle of Mull } & \text {. } & \text {. } & \text {. } & \text { B.M.N.H. }\end{array}$

Birterbuy Bay, Co. Galway . B.M.N.H.

Westport, Co. Mayo . . B.M.N.H.

Valentia, Co. Kerry . B.M.N.H.

Killiebegs, Co. Donegal B.M.N.H.

Norway

$$
\text { "Norway" . . . B.M.N.H. }
$$

Denmark

Bohuslen . . . . B.M.N.H.

France

U.Z.M.D.

Cette . . . . M.N.H.N.

Corsica

Bonifacio . . . . M.N.H.N.

U.S.A.

Wood's Hole, Mass. . U.S.N.M.

Marion Harbour, Mass. U.S.N.M.

Vinyard Sound, Mass. . U.S.N.M.

Rivers' Island, Mass. U.S.N.M.

Provincetown, Cape Cod. Mass. U.S.N.M.

Newport, Rhode Island U.S.N.M.

No Data . . . . U.S.N.M.

I 27 of 264 우 I 49 immature 64 oิ 67 우 21 immature I $\sigma^{*}$

5 oิ 5 우

I3 0 ํㅜ 6I 우

40 ô 50 o 45 immature

I 0 个 I 우

4 ô 5 우 I immature

I oิ 9 우 3 immature

I 우

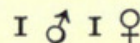

I ô I

20

7 ธิ26 우 I 2 immature

II 0 ô 17 우

2 우

I 5 ơ 18 우

2 ㅇ

2 수 3 우

5 워 23 우 2 immature

I 우

\section{Microdeutopus damnoniensis (Bate)}

England

Plymouth, Devon ‥M

Wembury, Plymouth, Devon. B.M.N.H. 4 ㅇ PARALECTOTYPES

Drake's Island, Plymouth 
Channel Islands

\section{Location No. of Samples}

Material

Jersey .

Guernsey .

France

Bandol
B.M.N.H.

B.M.N.H.

M.N.H.N.
I

I

I

Microdeutopus algicola Della Valle

Italy

*Naples . . . . B.M.N.H.

Algeria

Bône

. M.N.H.N.
2 주 4 우

6 수 10 우 2 immature

Microdeutopus schmitti Shoemaker

U.S.A.

Point Conception, California U.S.C.

Point Loma, California . U.S.C.

San Clemente, California . U.S.C.

Newport, California . . U.S.C.

Mexico

El Coyote, Baja California . U.S.N.M.

Bahia de San Quintin,

Baja, California . . U.S.N.M.

Bahia de Magdalena .

Baja California . . U.S.C.

Costa Rica

Bahia de Salinas . . U.S.N.M.

Playa Blanca . . . U.S.N.M.

South Viradores Islands U.S.N.M.

24 ऽิ 64 우 24 immature

5 ธิ 5 우 2 immature

3 б수 2 우

3 бำ 6 으 I immature

I 0

7 ชิ 19 우

2 우

5I 4 ơ 26I 우 50 immature 3 o

I ठิ

Microdeutopus hancocki Myers

Costa Rica

Bahia de Salinas $\quad$. U.S.N.M. 2

Panama

Bahia Honda . . U.S.N.M.

Equador

Salango Island . . . U.S.N.M. I

Galapagos

Isabela Island ． ～. . U.S.N.M.

2I $₫$ TYPE MATERIAL

I2 0 23 우 4 immature

I $\widehat{0}$

21 đิ 23 우 4 immature

Microdeutopus trichopus Myers

Galapagos

Isabela Island • • • U.S.N.M.

38 ơ 3 ㅇ TYPE

MATERIAL

Microdeutopus sp. nov?

U.S.A.

Tortugas, Florida _ • . U.S.N.M

2

2 б지우

Microdeutopus armatus Chevreux

France

* Le Croisic . . . B.M.N.H.

* Antibes . . . . M.N.H.N.

3 주 3 우

2 주 8 우

*Villefranche . . . M.N.H.N.

I3 0 I 17 우 


\section{$2 \mathrm{BHL}$ Biodiversity Heritage Library}

1969. "A revision of the amphipod genus Microdeutopus Costa (Gammaridea: Aoridae)." Bulletin of the British Museum (Natural History) Zoology 17, 91-148. https://doi.org/10.5962/bhl.part.10337.

View This Item Online: https://www.biodiversitylibrary.org/item/19623

DOI: https://doi.org/10.5962/bhl.part.10337

Permalink: https://www.biodiversitylibrary.org/partpdf/10337

\section{Holding Institution}

Natural History Museum Library, London

\section{Sponsored by}

Natural History Museum Library, London

\section{Copyright \& Reuse}

Copyright Status: In copyright. Digitized with the permission of the rights holder.

Rights Holder: The Trustees of the Natural History Museum, London

License: http://creativecommons.org/licenses/by-nc-sa/4.0/

Rights: http://biodiversitylibrary.org/permissions

This document was created from content at the Biodiversity Heritage Library, the world's largest open access digital library for biodiversity literature and archives. Visit BHL at https://www.biodiversitylibrary.org. 